\title{
Democracy with Chinese Characteristics: A Political Proposal for the Post-Communist Era
}

\author{
Daniel A. Bell \\ Philosophy East and West, Vol. 49, No. 4. (Oct., 1999), pp. 451-493.
}

Stable URL:

http://links.jstor.org/sici?sici=0031-8221\%28199910\%2949\%3A4\%3C451\%3ADWCCAP\%3E2.0.CO\%3B2-8

Philosophy East and West is currently published by University of Hawai'i Press.

Your use of the JSTOR archive indicates your acceptance of JSTOR's Terms and Conditions of Use, available at http://www.jstor.org/about/terms.html. JSTOR's Terms and Conditions of Use provides, in part, that unless you have obtained prior permission, you may not download an entire issue of a journal or multiple copies of articles, and you may use content in the JSTOR archive only for your personal, non-commercial use.

Please contact the publisher regarding any further use of this work. Publisher contact information may be obtained at http://www.jstor.org/journals/uhp.html.

Each copy of any part of a JSTOR transmission must contain the same copyright notice that appears on the screen or printed page of such transmission.

JSTOR is an independent not-for-profit organization dedicated to and preserving a digital archive of scholarly journals. For more information regarding JSTOR, please contact support@jstor.org. 


\title{
DEMOCRACY WITH CHINESE CHARACTERISTICS: A POLITICAL PROPOSAL FOR THE POST-COMMUNIST ERA
}

\author{
Daniel A. Bell \\ Department of Philosophy, University of Hong Kong
}

\section{SCENE I. The Discussion Begins}

Beijing University, June 3, 2007. SAM DEMO, program officer for a U.S.-based prodemocracy think tank, steps into the office of PROFESSOR WANG to begin a prearranged interview. PROFESSOR WANG, a respected political philosopher at Beijing University in his mid-forties, has been selected to participate in a constitutional convention due to begin the following day in Beijing.

DEMO: [Out of breath] Thank you for receiving me today. I realize it must be a very busy time now. [Pause.] I'm sorry I'm late. I was stuck in traffic for over two hours.

WANG: I guess that's the price a society pays for economic development. One reads in the textbooks that modernization is supposed to increase the pace of living, but the opposite may well be the case.

DEMO: [Laughs] It could be worse: in the mid-1990s, the average commuter in Bangkok had to bring a potty in his car. But the traffic situation improved after the economic crash. [Short pause.] Well, I still find it hard to believe we're here to discuss the prospects for democratic political reform in China, and no need to worry about the secret police. Think about it. Five or six years ago, who would have been able to anticipate the possibility of a national convention designed to formulate a democratic constitution appropriate for China?' And on June Fourth, no less!

WANG: In retrospect, it may not seem that remarkable. Remember we had a fairly open debate about political reform in the late 1980s, prior to the Tiananmen massacre. People tend to forget that the Communist Party itself set up a Political Reform Office which sometimes evaluated radical proposals for political change. And Deng's death seemed to open up some possibilities. New signs of tolerance emerged at the Communist Party's fifteenth Congress in October 1997, and intellectuals began to speak out for political reform once again. ${ }^{2}$ Besides, the Party couldn't postpone the day of reckoning forever, marking the days prior to the June Fourth anniversary with detentions, tighter surveillance of leading dissidents, controlling access to Tiananmen Square, and so on. Once again, it's easy to say this in retrospect, but in my view it was inevitable that the Party would apologize for the Tiananmen massacre, just as the KMT apologized for the February 28, 1947, massacre (though it took over four decades) and the Korean government indicted those responsible for the 1980 Kwangju massacre more than ten years after the fact. And after Li Peng had retired, it was no longer possible to hold back demands for political reform. 
DEMO: Well, stranger things have happened. How many of us managed to predict the sudden collapse of the Soviet empire, ${ }^{3}$ or the swift and peaceful dismantling of apartheid in South Africa? [Short pause.] I'm still not too clear, however, about your proposal for tomorrow's constitutional convention. I've heard it said that you favor a democratic political system "with Chinese characteristics." What does this phrase mean? I'm well aware that Chinese reformers typically argue for democracy as a means for strengthening national power ${ }^{4}$-in contrast, say, to American theorists, who tend to justify democracy with reference to the value of individual freedom $^{5}$-but this is a dispute over the justification for a democratic political system. I've yet to hear an argument, I must admit, that a unique kind of democratic system is appropriate for this part of the world, one that differs to a significant extent from Western-style democratic institutions. In other words, both Asians and Westerners seem to agree on the political ideal, though they may typically do so for different reasons.

WANG: Let me try to explain my scheme. I do in fact have a proposal for a different kind of democracy, a democratic political system that's particularly appropriate for the Chinese context. And tomorrow I'll try to persuade fellow Chinese, although I think foreigners can also come to appreciate my reasons for defending this scheme.

DEMO: Please elaborate.

\section{[On the Need for Capable and Far-sighted Rulers in Modern Societies]}

WANG: Well, we agree that a democratic system at minimum must include regular elections based on universal franchise. The aim is to give ordinary citizens a say, no matter how distant, in political decision making, and to hold political rulers accountable at the end of the day. But it's also the case that many relevant issues and policies in the political systems of modern societies have become so complex that most ordinary citizens can't even begin to make sound judgments. Does the man on the street really know the probable impact of increasing interest rates or reforming administrative law? The sheer complexity of public affairs in the modern era means that a substantial amount of decision-making power must be placed in the hands of an intellectually agile and well-qualified elite, almost as a functional requirement of modern political societies. More than ever before, there's a need for "brains" in government.

DEMO: Fair enough. But on the other hand, many modern societies seem to function quite well with a democratic system.

WANG: That's true. But those same societies also place substantial constraints on democratic majorities, presumably on the grounds that some things are better left to more "capable hands." I spent six years as a graduate student in the U.S., and I must say I was consistently shocked at the gap between the rhetoric of popular sovereignty and the reality of rule by an intellectual elite. One antidemocratic device, of course, is the constitutional Bill of Rights enforced by unelected judges holding final 
powers of review. The U.S. Supreme Court, as you know, has the power to override the decisions of elected politicians said to violate the U.S. Constitution.

DEMO: Mmm, yes. Perhaps you can also support your argument with the less well known example of central banks in Western societies. In the U.S., for example, the Federal Reserve Board has the power to make monetary policy, which can have important economic effects such as influencing peoples' decisions to buy consumer durables. ${ }^{6}$ This secretive institution is explicitly insulated against interference by elected politicians, on the grounds that it must have the power to take tough economic decisions that benefit the country in the long run. So, for example, the Fed sometimes increases interest rates so as to ward off inflation, even if this means increasing unemployment. A more responsive central bank might not be able to act against the wishes of politicians who might find it in their interest to combat unemployment, whatever the long-term economic consequences. There seems to be an implicit understanding that secrecy and insulation from political pressure is essential to the successful conduct of monetary policy, and that most elected politicians have neither the competence nor the political will to make sound economic decisions. ${ }^{7}$

WANG: Yes, that's a good example.

DEMO: But keep in mind that "the people" still have the ultimate power. Super majorities have the power to amend the U.S. Constitution, ${ }^{8}$ though admittedly it's a time-consuming and difficult process. And Federal Reserve Board governors are appointed by the president and have to be confirmed by the Senate.

WANG: I wonder if this "ultimate power" means much in practice. ${ }^{9}$ And when we look at the democratic political systems in East Asia, it seems that intellectual elites have an even greater say relative to elected officials. In Japan, meritocratically chosen bureaucrats continue to wield power and authority that would make even their semi-fictitious colleagues in Yes Minister envious. The political system empowers them to make the most of the nation's policy, and they effectively answer to no one, including the nation's elected politicians. ${ }^{10}$

DEMO: But do you endorse this kind of system? Isn't there a need for more openness and accountability in the Japanese political system? There's no need to remind you of the Ministry of Finance's role in prolonging, if not causing, Japan's crippling economic crisis in the 1990s. ${ }^{11}$ And let's not mention that incident involving bureaucrats at the Health Ministry, who resisted allowing imports of sterilized blood until 1985, well after they had been told of the risks of HIV contamination. As a result, several hundred Japanese hemophiliacs died from AIDS. ${ }^{12}$

WANG: Of course intellectual elites make tragic mistakes, but so do elected politicians. I worry about political systems which empower "feel good" politicians, who manage to get elected by promising the moon to their constituents- "we'll cut taxes and increase spending," or "full steam ahead with economic development," the story goes-and never mind the long-term consequences. Let future generations worry about massive deficits and ecological disasters.

DEMO: Fair enough. But you may be overestimating the intelligence of some elected politicians. Not all of them consciously subordinate the long-term good for 
short-term gain. Ronald Reagan, for example, seemed too intellectually feeble to even grasp the long-term implications of what he proposed.

WANG: [Smiles] For better or for worse. He was playing with fire, but he did fuel an arms race that contributed to the economic collapse of the Soviet bloc. In any case, from my perspective the ideal is a political system that guarantees bright and farsighted rulers and yet holds them somewhat accountable for what they do. The problem with the Japanese system is that "bureaucrats" - in effect the nation's top political decision makers-decide things in secret and then can't be held responsible when things go wrong.

DEMO: We seem to have come a long way from democracy. A democratic system simply can't ensure that a country's top decision makers will be "bright and farsighted." The rulers are whoever the people say they are, and it must be assumed that ordinary citizens can generally be trusted to choose the right sorts of leaders.

\section{[A Confucian Tradition of Respect for a Ruling Intellectual Elite]}

WANG: You see, this is where cultural differences may be relevant. In East Asia, to put it a bit crudely, the tradition has been to place trust in competent and virtuous bureaucrats. As you may know, East Asian political culture has been shaped by the Confucian idea that public service is the way to achieve complete self-realization. There's a saying in the Confucian Analects. [Short pause.] Let me try to translate:

Tzu-lu asked about the qualities of a true gentleman. The Master said, He cultivates in himself the capacity to be diligent in his tasks. Tzu-lu said, Can he not go further than that? The Master said, He cultivates in himself the capacity to ease the lot of other people. Tzu-lu said, can he not go further than that? The Master said, He cultivates in himself the capacity to ease the lot of the whole populace. If he can do that, could even Yao or Shun find cause to criticize him? $(14: 45)^{13}$

Promoting the common good, according to this view, is life's highest achievement, and this sort of idea may have inspired the "best and brightest" in East Asia to compete for civil service appointments. ${ }^{14}$ Not surprisingly, occupants of bureaucratic posts have typically been held in high regard by the population at large, in the same way that self-made entrepreneurs in the U.S. tend to be granted large amounts of respect.

DEMO: Correct me if I am wrong, but Plato also proposed a political system of "rule by the wise." The value of political elitism is not foreign to the West, I can assure you.

WANG: But there's a difference. Plato's philosopher-king is burdened with the task of public duty - true self-realization lies "outside the cave," in the realm of the ideal forms. The same goes for Aristotle, for whom intellectual contemplation is the highest pleasure. And when we turn to Christianity, the bias against "secular" public service is even more deeply felt-one lives, and suffers, in "the city of man" in order to find happiness in "the city of God." [Short pause.] Now, I don't mean to deny that some Chinese philosophical systems also devalue the political-Daoism comes to mind ${ }^{15}$ - but certainly the dominant philosophical tradition in East Asia values public 
service over and above other activities. And all the world is promised to those who succeed.

DEMO: I think you may be overestimating the sociological importance of philosophical texts.

WANG: Perhaps. But recall that Confucian societies institutionalized a stable mechanism capable of producing, at least on occasion, what was widely seen as a "government of the best men" - China's famous two-thousand-year-old meritocratic civil service examination system. Entry into the civil service through competitive examination was open to all males, with few exceptions, and those who eventually succeeded at passing, often having to undertake half a lifetime of study to do so, were thought to be in sole possession of the moral and intellectual qualities necessary for public service. [Short pause.] Think about it. In the West, defenders of rule by an intellectual elite could do nothing more than argue in favor of their superior abilities in political-theory texts, universities, churches, and so on, whereas Confucians could actually prove themselves by succeeding in a fair and open examination process. I think this helps to explain why scholar-bureaucrats were granted uncommon (by Western standards) amounts of legitimacy, respect-and power.

DEMO: But look at what happened in China-the communists uprooted the traditional value of rule by an intellectual elite and its institutional manifestations. There's no need to remind you of the Cultural Revolution.

WANG: You're right, but ideology began to take a back seat to considerations of talent and expertise with the advent of economic reform. In the Deng reform era, intellectuals were again held in high esteem and regarded among the leaders of the country. ${ }^{16}$ And when we look at the May-June 1989 pro-democracy demonstrations -recall that over one million ordinary Beijing citizens participated in a movement that was led by students and intellectuals from China's most prestigious universities -it becomes clear that the value of respect for the leadership role of an intellectual elite was not killed off by the Cultural Revolution. ${ }^{17}$ Of course, it's much easier to trace philosophical and institutional continuity in other East Asian countries fortunate enough not to have experienced a full-scale Cultural Revolution. ${ }^{18}$ In Japan, the top candidates in the nationwide pre-university examination system enter the Law Faculty at Tokyo University, and upon graduation they obtain posts with the most prestigious government ministries. In Singapore, the top graduates from the National University compete not for prime jobs in the private sector but rather for the best jobs in government. And those who scored highest on their "A levels" are given government scholarships to study abroad at Princeton, Harvard, and such, and when they return to Singapore they're almost immediately given responsible positions in the public sector. Moreover, as a condition of having accepted the scholarship they're under a legal obligation to work for the government for a minimum of eight years. How's that for a productive use of talent!

DEMO: Are you suggesting that China should revive the Confucian practice of rule by meritocratically chosen government bureaucrats?

WANG: Not exactly. As I said, I favor some accountability for political decision making, which was lacking in traditional Confucian societies, and still seems to be 
lacking in Japan and Singapore. And I think the political-talent selection procedures should be made more open than they currently are in East Asia. But I also want to preserve the Confucian political value of conferring respect and power to an intellectual elite, on the grounds that modern societies generally fare better if they're ruled by bright and farsighted public servants. So the challenge is to how to implement dual commitments to democracy and rule by a public-spirited intellectual elite in a contemporary Chinese context.

DEMO: [Intrigued, yet slightly skeptical] And what's the answer?

\section{SCENE II. The Alternatives}

WANG: Well, I racked my brains for many years trying to resolve this question. I considered various alternatives, but none seemed to offer a persuasive way out. [Short pause.] The solution, strangely enough, came to me one day as I was having lunch at the Kentucky Fried Chicken outlet at Tiananmen Square.

DEMO: [Laughs] Why not? In the old days, philosophers like Jean-Jacques Rousseau had sudden revelations under oak trees, ${ }^{19}$ but it seems to be getting more and more difficult to find greenery in Beijing.

WANG: Of course I'm not comparing myself to Rousseau, although I won't deny that it was a moment of tremendous excitement when I thought of this political arrangement.

DEMO: [Getting more curious] Well, let's have it.

WANG: The tricky part was how to institutionalize rule by an intellectual elite in an overall democratic context. I never had any difficulty with the question of institutionalizing the democratic component of the equation-any workable and legitimate political system in the modern era must, I think, include free and fair competitive elections. But how to ensure a "government of the best"?

DEMO: What about letting the people decide?

WANG: I'm not too sure about that. Sometimes politicians can only get elected by pandering to the short-term interests of the populace. In developing countries it's often easier to get elected by promising the conditions for rapid economic development, regardless of the ecological costs for future generations. In developed countries, voters prefer politicians who favor policies that benefit the middle class and the rich, regardless of the impact on the poor. Or sometimes they promise to maintain economically unsustainable welfare benefits.

DEMO: Democracy isn't perfect. But if the solution is to give more power to an intellectual elite, then democratic elections may do the trick in East Asia. As you suggest, ordinary people have imbibed the ethic of respect for Confucian "gentlemen," so one should expect citizens to vote for such persons.

WANG: That's possible. In Korea and Taiwan, for example, candidates for national office often flaunt their educational qualifications, apparently with the hope that people are more inclined to vote for a ruler with a Ph.D. from a prestigious university. But overall, the situation is not encouraging. In Japan, voters appear to be 
swayed primarily by short-term material benefits, and still now, most political talent finds its way to the bureaucracy rather than the legislature. And even supposing that voters try to identify "Confucian" political rulers, they may not always be able to identify persons of character and ability. The Singapore government controls for this possibility by administering a battery of tests to PAP candidates, including an IQ test and other psychological tests to eliminate candidates who are selfinterested. ${ }^{20}$

DEMO: But you don't have truly competitive elections in Singapore. The Singapore government also controls for the possibility of "bad" rulers by numbering ballots, humiliating and bankrupting opposition candidates, and instilling an atmosphere of fear in the population at large. That's not what you want for China, is it?

WANG: No, of course not. But neither do I want to leave it all up to "the people." It's simply too risky in China. Most people are still uneducated peasants, and....

DEMO: [Interrupting] Now hold on a second. Peasants-or perhaps "farmers" is a more politically correct word-already vote in China. Surely you're familiar with the village democracy program, with farmers choosing among candidates competing for posts on village committees. Even the Communist Party endorsed this program in the mid-1990s, on the grounds that local leaders needed to be made more accountable. ${ }^{21}$ You're not against that, are you?

WANG: No, no, don't be silly. Of course "farmers" should choose the leaders of village committees. They should have the power to remove corrupt local leaders from office. But do you think "farmers" are qualified to choose national political rulers deciding such complex matters as macroeconomic management and foreign policy? I'd be nervous about granting too much power to relatively uneducated people, and I know many "democrats" also worry about the possibility of a farmerdominated legislature. ${ }^{22}$ In China, the problems we face are so severe-overpopulation, pollution, increasing economic inequality, a risk of civil war-that's it's just too much of a gamble to invest all our hopes in the capricious likes and dislikes of a largely rural population in a free-for-all political fest held every four or five years.

DEMO: But what are the alternatives?

WANG: Exactly. Remember, I don't have a quarrel with democracy per se. My aim is simply to temper the democratic process with a concern for the selection of talented decision makers. And, to repeat, even Western societies like the United States do in practice place constraints on the decision-making powers of elected politicians. But your solutions may not be readily transferable to our country, and the question is how to combine democracy with a stable, legitimate, and effective system of rule by an intellectual elite in a Chinese context.

\section{[Plural Voting Schemes]}

DEMO: This reminds me of Lee Kuan Yew's proposal for a plural voting scheme. Lee, as you know, isn't convinced that the one-man, one-vote system is the best way to 
select a government of the "best men." So he floated the idea of giving middle-aged family men two votes on the grounds that they're supposedly more likely to be careful, voting also for their children. Lee said that young men bent on immediate gratification are more likely to vote in a capricious way, not taking into account the interests of others, and that elderly people are also focused on short-term, supporting policies like free health care, which may harm the economic prospects of future generations. ${ }^{23}$ Is this what you have in mind?

WANG: No. I considered Lee's idea, as well as John Stuart Mill's proposal for granting extra votes to educated people on the grounds that they're less likely to vote in accordance with material interests. ${ }^{24}$ But I rejected these schemes, as well as other proposals for giving extra votes to certain groups of citizens.

DEMO: Why is that?

WANG: I concluded that plural voting schemes are simply too arbitrary. I accept the premise that not everyone is equally inclined to vote in a sensible manner, but selecting target groups of "rational" voters is a rough and unreliable procedure. And those denied an equal share of democratic rights are likely to perceive the denial as an official insult issued by public authority. ${ }^{25}$ People would object to being treated as unequals at the very start of the political process. [Short pause.] It boils down to the fact that I could never get past the question of "who decides?" If the government decides who gets the extra votes, people may think the government is motivated by a desire to select the groups most likely to perpetuate dominance of the ruling party. Recall what happened last year in Singapore: Lee tried to implement his proposal, but it was blocked after the opposition Singapore Democratic Party embarrassed the government with a study from a National University of Singapore sociologist-the poor fellow paid with his job-which showed that middle-aged family men are twice as likely to vote for Lee's party, relative to any other segment of the population. Of course, Singapore-style clampdowns on dissenting views makes this proposal particularly problematic.

DEMO: But giving people extra votes would also be problematic in a more democratic context. Political parties would promise special favors to groups with extra votes, ${ }^{26}$ and elected officials might try to award extra votes to their own constituencies, regardless of merit. It would be a mistake to let politicians decide these matters.

WANG: I agree. And there are no obvious alternatives to letting politicians decide these matters. Who would trust an "independent" body of social science experts to identify the groups most likely to vote for competent and public-spirited rulers? Even if it were feasible, who would appoint this body?

DEMO: You won't get any objections from me. Things could get even more complicated. The "target group" of sensible voters may change over time, so I imagine this body of social science experts would have to revise the "extra-voting" rules at every election.

WANG: Yes. No one could be trusted with this sort of power, in a Chinese context or anywhere else. So I dropped the idea of extra-voting proposals. 


\section{[A Corporatist Assembly]}

DEMO: O.K., let's move on to your own proposal.

WANG: We'll get there eventually. For a while, I was also tempted by Hegel's account of the ideal state in the Philosophy of Right.

DEMO: You mean his argument for investing power in disinterested civil servants, chosen on the basis of competitive examinations? ${ }^{27}$ I can see why you'd be tempted by Hegel's political views.

WANG: Actually, from a Chinese perspective, there's nothing particularly original about Hegel's argument for an impartial civil service. I was most interested by Hegel's attempt to reconcile political rule by expert bureaucrats with a concern for representing the voices of different segments of society. He argued for a bicameral legislature, an upper house of the landed propertied class, and a lower house of corporations and professional guilds. The legislature would serve the function of helping the civil servants to make rational decisions by providing detailed information on the urgent and specialized needs of particular constituencies. He argued as well that the legislature should hold its deliberations in public, hence developing the political virtues and abilities of the legislators and educating "the masses" about the various ways political bodies help to promote the common good of the polity. Hegel recognized that individuals are now interested in the conduct of the state's affairs and want a voice in determining its policies, and he concluded that only an open and transparent assembly could instill respect for political institutions.

DEMO: But he opposed direct suffrage!

WANG: That's correct. Hegel worried that individuals not tied to any groups or organizations would, in his words, be "elemental, irrational, barbarous, and terrifying." Anticipating Tocqueville's argument on the importance of civil society for promoting civic virtue, Hegel argued that individuals come to take an interest in common enterprises and to develop a certain degree of political competence only by joining and participating in voluntary associations and community groups. That's why Hegel favored a lower house composed of corporations and professional guilds-whereas individuals are likely to vote with their pocketbooks, representatives of corporate bodies would in all probability display a certain amount of organizational ability and concern for the common good.

DEMO: It's worth keeping in mind that Hegel's scheme was implemented by Mussolini and his National Union of Fascists, who held that corporatism was a way of eliminating social conflict by integrating the people through their work groups into the state. ${ }^{28}$

WANG: I think that's unfair. Hegel may not have been a democrat in the sense of favoring universal suffrage, but he was still a kind of liberal, concerned with articulating the social framework within which freedom can be realized. ${ }^{29}$ It's just that he thought the modern aspiration for freedom could best be sustained in a nondemocratic political context.

DEMO: Fortunately history has proved him wrong. 
WANG: I'm not so sure. Consider the Legislative Council of Hong Kong in the 1980s and '90s, perhaps the closest approximation anywhere to Hegel's corporate assembly. ${ }^{30}$ De facto power in Hong Kong, it seems, was more often than not exercised by a group of relatively able and honest "Hegelian" —or should I say "Confucian"? - bureaucrats in the colonial administration. But the composition of the Legislative Council is more relevant for our purposes. From 1844 right up to 1985, all members of the Council were directly appointed by the Governor. In order to represent more authoritatively the views of Hong Kong people, however, the government decided to institute elections for a number of the seats. But it disparaged the idea of introducing direct elections by universal suffrage on the grounds that this might lead to instability at a crucial time. So the government decided that a large number of seats should be allocated to functional constituencies based on various interest groups, a system that was kept in place following the handover to China. ${ }^{31}$ Doctors and dentists had one seat, as did teachers, lawyers, engineers, and accountants. The largest chunk of functional constituency seats went to business interests, such as the Chinese Manufacturer's Association, the Chinese Gold and Silver Exchange, and the Hong Kong Tourist Association. Altogether twenty-one out of sixty seats were allocated to functional constituencies, a number that increased to thirty in the 1995 and 1998 elections. As far as I know, this was a truly unique "Hegelian" legislative assembly -in no other country at the time was the largest block of seats in a house of government assigned to business groups and professional organizations. $^{32}$

DEMO: But this wasn't a stable and legitimate political arrangement. The Hong Kong people wanted the right to vote!

WANG: That's not immediately obvious. When they were given the opportunity to exercise the right to vote for a limited number of seats in 1991 and 1995, only 30 percent or so bothered turning out for the elections.

DEMO: But in 1998 that number increased to over 50 percent. And voter turnout would have been even higher if people had actually been voting for their community's most important decision makers. Remember, in Hong Kong, the unelected members of the executive made policy, and elected members of the legislature functioned more as opposition critics than as legislators.

WANG: I actually agree with you. I was playing the role of-how do you say it? "devil's advocate"....

DEMO: Yes. This term comes from an established practice of the Catholic Church. At the canonization of a saint, the Church appoints and listens carefully to a "devil's advocate." The idea is that even the holiest of men can't be admitted to posthumous honors until all that the devil could say against him is known, weighed, and refuted.

WANG: I remember reading about that in John Stuart Mill's work. ${ }^{33}$ The Confucian equivalent is the "Censor," who was obligated to protest against bad officials and harmful policies. It was a risky job, and some high-minded Confucian officials paid with their lives. ${ }^{34}$ [Short pause.] In any case, my point is that the right to vote, for whatever reason, seems to have emerged as an ineliminable symbol of political 
recognition for citizens in the modern world. No polity that denies the right to vote, I think, can ever hope to achieve a stable and legitimate political system. In that sense, Hegel was quite mistaken when he predicted that given the opportunity to participate in mass elections, with individual votes having little effect, citizens would inevitably become indifferent and fail to make use of the vote.

DEMO: Let me support that with the observation that political apathy tends to be even higher in political regimes like Singapore, which place substantial constraints on the electoral process. ${ }^{35}$ [Short pause.] But I'm a little confused. It seems that you do not, after all, endorse Hegel's proposal for a corporatist legislative assembly.

WANG: No, definitely not. Hong Kong tried to make do without a fully elected assembly, but it never did achieve much legitimacy among ordinary citizens, who placed more value on universal suffrage. Denying most people the right to vote, in other words, just didn't work. The second problem with Hegel's proposal can also be vividly illustrated with the Hong Kong case. The small size of most functional constituencies meant that it was possible for the voters to keep a close watch on what their representative was doing, and to instruct him on what he should say and how he should vote. In one case, the Chairman of the Hong Kong General Chamber of Commerce publicly rebuked its representative-I believe McGregor was his name-for voicing liberal views in the Legislative Council that didn't have the Chamber's support. ${ }^{36}$ It was the same old story after the handover: professionals asked their representatives to protect their own interests in making a living rather than serving the community as a whole. ${ }^{37}$ In short, most functional constituency representatives were serving the narrow concerns of the richest and most privileged sectors of the community. You can imagine the effect this had on the legitimacy of the functional constituency system in the polity at large.

DEMO: Mmm.... Just as Hegel may have underestimated the importance of the right to vote for ordinary citizens in modern societies, so he seems to have overestimated the capacity of "corporate" representatives to function as more than servants of powerful interest groups.

\section{[A Parliament of Scholar-Officials]}

WANG: Exactly. So I had to consider other options for tempering democracy with a concern for institutionalizing rule by an intellectual elite in China. I was most inspired by Huang Zongxi's proposals for political reform. Huang was a radical seventeenth-century Confucian critic of the Chinese dynastic system....

DEMO: [Interrupting] Did you say Confucian critic of the Chinese dynastic system? I was under the impression that Confucian mandarins were loyal supporters of imperial power. Isn't there something in the Analects about learning the virtue of obedience in the family in order to instill habits of obedience to the ruler?

WANG: I think you're referring to the following passage:

Master Yu said, Those who in private life behave well towards their parents and elder brothers, in public life seldom show a disposition to resist the authority of their superiors. And as for such men starting a revolution, no instance of it has ever occurred. It is upon 
the trunk that a gentleman works. When that is firmly set up, the Way grows. And surely proper behavior towards parents and elder brothers is the trunk of Goodness? $(1: 2)$

The point here is to stress that the family is the main educative institution for learning morality. Morality, however, doesn't mean blind obedience-even in the context of the family; later in the Analects Confucius says "In serving your father and mother you ought to dissuade them from doing wrong in the gentlest way" $(4: 18){ }^{38}$ So the family may be an important institution for instilling the virtue of respect for legitimate authority, but even filial sons have an obligation to persuade parents to refrain from wrongdoing. ${ }^{39}$

DEMO: I must say I'm quite impressed. You seem to have memorized the whole of the Analects.

WANG: Well, there's been somewhat of a resurgence of tradition lately, and you'd be surprised just how many educated Chinese can recite passages from "sacred" texts. Besides, the Analects is only one hundred pages or so; it's not like the Bible.

DEMO: [Smiles] Is pithiness a Confucian virtue?

WANG: Yes, actually. There's a strong bias in Confucianism against eloquence and clever argumentation not matched by the required actions. As Confucius put it, "A gentleman covets the reputation of being slow in word but prompt in deed" (4:24; see also $14: 29)$. [Short pause.] In any case, I was hoping to return to the doubts you expressed about the critical potential of Confucianism. Remember that Mencius-Confucius' most famous follower-went so far as to justify the assassination of rulers who fail to serve the people's interests. ${ }^{40}$

DEMO: But you seem to be drawing only on the "liberal" parts of the Confucian tradition, leaving out the rest. Unfortunately, "actually existing" Confucianism tended to draw more on the part that supported the authoritarian, hierarchical status quo. ${ }^{41}$

WANG: It's not that simple. The critical potential of Confucianism also influenced the practice. In fact, Confucianism was challenged by its rivals precisely on the grounds that Confucian morality fails to instill political obedience. Han Fei Tzu, for example, repeatedly attacked Confucian "wandering scholars" (sec. 49) ${ }^{42}$ for sowing a critical attitude vis-à-vis the laws of the land.

DEMO: Say that again?

WANG: I was referring to Han Fei Tzu, the major synthesizer of Legalist thought. Han Fei was a profoundly cynical proponent of realpolitik-Machiavelli was a naive idealist in comparison. He wrote a political handbook for rulers, arguing that state power can be strengthened by means of harsh laws and punishments. His aim was nothing less than total state control, and he stressed that moral considerations should not get in the way. Not surprisingly, rulers were quite receptive to this sort of advice, starting with the ruthless King of $\mathrm{Ch}^{\prime}$ in, who ascended to the throne in 246 B.C. and drew on Han Fei's advice to conquer and rule all of China under the title of First Emperor of the $\mathrm{Ch}^{\prime}$ in dynasty. [Short pause.] In any case, Han Fei had nothing but contempt for Confucian morality. He was understandably horrified, for example, by 
the famous Confucian argument that the requirements of filial piety justify breaking the law.

DEMO: Did Confucius really say that?

WANG: Yes. Let me quote the Analects once again:

The "Duke" of She addressed Confucius saying, In my country there was a man called Upright Kung. His father appropriated a sheep, and Kung bore witness against him. Confucius said, In my country the upright men are of quite another sort. A father will screen his son, and a son his father-which incidentally does involve a sort of uprightness. $(13: 18)$

Han Fei recounted this episode, and his view was, of course, quite unfavorable. He added another story - probably a fabrication-about Confucius rewarding a man for running away from battle in order to care for an aged father, with the result that the people thought nothing of surrendering or deserting (sec. 49). The "family over state $^{\prime \prime}$ principle, in Han Fei's view, is incompatible with successful warfare, and more generally Han Fei urged governments not to promote Confucian values.

DEMO: I suspect that Han Fei may have been agonizing over a nonissue. No government would promote a moral system that justifies breaking the law!

WANG: You'd be surprised. Filial piety as a preeminent value was in fact enshrined by law in Imperial China. Already in Han times people were permitted to conceal the crimes of close relatives without legal penalty, and they weren't compelled to testify in court against family members. ${ }^{43}$ In the Ching dynasty, a son who brought an accusation of parental wrongdoing before the authorities was subject to strangulation if the accusation was false, and even if it was true the son was punished with three years of penal servitude plus one hundred blows of the heavy bamboo. ${ }^{44}$ Scolding one's parent or grandparent was punishable by death. ${ }^{45}$

DEMO: [Stunned] Really!

WANG: Yes. So remember, my point is to stress that realpolitik types in Imperial China criticized Confucianism for encouraging disobedience and fostering a critical perspective vis-à-vis the state. Far from justifying blind adherence to the political status quo, Confucian values often provided the intellectual resources for social critics. ${ }^{46}$

DEMO: My perception of Confucianism must have been influenced by Lee Kuan Yew, who appeals to Confucianism to buttress authoritarian rule.

WANG: It's a sad fact of the real political world that rulers often distort ideas to suit their own narrow political agendas. No doubt Marx as well would also have been horrified by what people did in his name. [Short pause.] In any case, perhaps I should return to that seventeenth-century Confucian scholar Huang Zongxi. Huang's book Waiting for the Dawn: A Plan for the Prince is a powerful Confucian critique of despotism. Let me try to remember a relevant passage. [Short pause.] Well, in the very first chapter Huang says: "In ancient times all-under-Heaven were considered the master, and the prince was the tenant. The prince spent his whole life working for all-under-Heaven. Now the prince is the master, and all-under-Heaven are tenants. That no one can find peace and happiness anywhere is all on account of the 
prince." 47 This was written around the time of the collapse of the Ming dynasty. Huang was resisting the conquest of China by the Manchus, who went on to found the Qing dynasty.

DEMO: And how did the new Manchu emperor react to this point of view?

WANG: Huang wasn't so foolish as to publicize his ideas. Judging by his scornful characterization of "actually existing" dynastic rule, it's unlikely that Huang was actually addressing the emperor of his day. ${ }^{48}$ Huang's hope, it seems, was that a future ruler inclined toward benevolence would seize his ideas to build what we might term a just political order.

DEMO: So how did the book get transmitted to future generations?

WANG: Well, initially it was distributed to a few colleagues and students. His book was then circulated "samizdat" — pardon the anachronistic language-for two and a half centuries, finally seeing the light of day in the latter part of the Qing period, with the dynasty in disarray. Huang came to be acclaimed by late nineteenthand early twentieth-century reformers as an early champion of native Chinese "democratic" ideas. ${ }^{49}$ For example, Liang Qichao-China's most famous writer in the early twentieth century-reprinted Huang's book to provide more ammunition for political reform. ${ }^{50}$

DEMO: Did Huang provide any concrete alternative to dynastic power, or was he merely criticizing the status quo?

WANG: That's what's interesting. Unlike most Confucians, he went beyond merely affirming the need for a virtuous ruler of exemplary character, arguing for specific laws and institutions designed to curb imperial power. Huang favored establishing a strong prime minister, so as to balance the power of the emperor ["Establishing a Prime Minister"]. If the aim is serving the people, according to Huang, then the role of ministers should be strengthened, and the emperor should welcome criticism from ministers who point to the plight of the people ["On Ministership"]. And I want you to pay special attention to his proposal for strengthening the political role of the schools for the training of Confucian scholar-officials. Schools of all levels, in Huang's view, should serve as forums for open public discussion. He noted that during the Eastern Han, A.D. 25-220, scholars at the Imperial College-the top school for the training of scholar-officials-engaged in outspoken discussion of important issues without fear of those in power, and the highest officials were anxious to avoid their censure. Moreover, Huang proposed that the rector of the Imperial College, to be chosen from among the great scholars of the day, should be equal in importance to the prime minister, and that once a month the emperor should visit the Imperial College, along with the prime minister and some other ministers. The emperor was to sit among the ranks of the students while the rector questioned him on the administration of the country ["Schools"].

DEMO: It sounds like "question time" in Parliament!

WANG: [Excited] Exactly! He wanted rulers to be held accountable to a "Parliament of Scholars"! 51

DEMO: [Pause] Now hold on a second. Is that what you're proposing for China? A Parliament of Scholars? How would you choose the scholars? 
WANG: The standard Confucian practice is to select scholar-officials on the basis of fair and open competitive examinations.

DEMO: Are Confucian examinations really appropriate for modern China? Correct me if I'm wrong, but examinations in Imperial China tested the memorization of the Confucian classics, and I doubt that's a sound basis for selecting a political ruling class in the contemporary era.

WANG: Once again, Huang Zongxi's proposals for reform are relevant. Huang condemned the examinations of his day for rewarding superficiality and plagiarism, and thus failing to identify men of "real talent." He didn't oppose testing knowledge of the classics and subsequent commentaries, but he emphasized that candidates must also offer their own interpretation of a question. To use Huang's own words-1 think I can get this right. .. " After listing one by one what is said by the various Han and Sung scholars, the candidate should conclude with his own opinion, there being no necessity for blind acceptance of one authority's word" ["The Selection of Scholar-Officials, Part I"]. The examinations should test for both the capacity to store information and the capacity for independent thought.

DEMO: Interesting. But let me ask you a question: what happened to democracy? If rulers are selected on the basis of competitive examinations rather than elections, how do "the people" fit in? How can ordinary people express their political will in your scheme, and how can they have control over the conduct of government?

WANG: That's precisely the problem with Huang Zongxi, 52 and with Confucianism more generally. The stress is on politics for the people, but there's not much on politics by the people. ${ }^{53}$

DEMO: [Frustrated] Now you've really lost me. You keep on switching back and forth. You seem tempted by the J. S. Mill/Lee Kuan Yew proposal for granting extra votes to more sensible and public-spirited voters, but then you admit that selecting the relevant target group can be an arbitrary process subject to political manipulation. You seem tempted by Hegel's idea of a legislature composed of representatives from community groups, but then you admit that in all likelihood this arrangement will unfairly benefit rich and powerful sectors, as it did in Hong Kong. You seem tempted by Huang Zongxi's proposal for a parliament of scholar-officials selected on the basis of competitive examinations, but then you admit that this political system deprives the people of any voice in politics. Sometimes you're a democrat, sometimes you're a Confucian. You want rulers of talent and character, but only in an overall democratic context. Can you have it both ways?

WANG: I guess you want to hear my own proposal.

DEMO: Yes! You've kept me waiting long enough.

\section{SCENE III. The Proposal}

WANG: Here it is. As I mentioned, the idea hit me one day in the Kentucky Fried Chicken outlet at Tiananmen Square. I was thinking to myself, if capitalism and communism can coexist in the economic realm, then why not democracy and Confucianism in the political realm? And then, all of a sudden, it seemed so obvious, 
and I must admit this is the first time in my life that a sudden illumination still seemed quite persuasive several months after the fact. The solution: a bicameral legislature, with a democratically elected lower house and an upper house composed of representatives selected on the basis of competitive examinations. I call the upper house the "House of Scholars."

DEMO: Mmm ... interesting....

\section{[Selection Procedures]}

[At this point a Beijing University graduate student named LI XUEDONG enters PROFESSOR WANG's office and stops, momentarily surprised to see DEMO.]

WANG: Let me do the introductions. This is Mr. Demo, an American friend who works with the National Council for Democracy, and [to DEMO] this is Li Xuedong, a doctoral student doing a thesis on Dzhaparidze's system of bimodel logic. [DEMO and LI XUEDONG shake hands.]

LI: Pleased to meet you. Is Professor Wang explaining his proposal for "democracy with Chinese characteristics"?

DEMO: Yes, what's your view?

LI: [Turning red] Well, you know, we never criticize our professors in China.

WANG: Please, Xuedong, tell Mr. Demo what you think.

LI: I generally support this proposal. My only concern is Professor Wang's idea that representatives of the House of Scholars be selected on the basis of competitive examinations. Here at Beijing University - the most prestigious university in China - many of our top undergraduates arrive fresh from the countryside. I'm not saying they're not smart, but they're good primarily at memorizing answers for the university entrance exams, and often they're not very sophisticated in other respects. Some of them change once they stay in Beijing for a few years, but I'd be worried about giving political power to narrow-minded young men and women.

DEMO: [Smiles.] You, I presume, are not from the countryside.

LI: I'm from Shanghai, which helps a bit.

WANG: Xuedong, I share your concern about rewarding young persons "fresh from the countryside." But more generally, I'd worry about being governed by overly clever young people no matter where they're from-imagine a House of Scholars full of arrogant and hot-headed twenty-year-olds! ${ }^{54}$ So I'd impose an age minimum for the examinations of, say, thirty-five or forty years.

DEMO: Perhaps I should also step in to defend the proposal. Professor Wang was telling me that he endorses Huang Zongxi's idea for examinations that test for both memorization and independent thought.

WANG: That's correct. I favor exams with an essay component, and I'd award high grades to those who can provide innovative yet plausible solutions to the questions we ask them. I'd also include one or two essay questions on ethics, to help filter out the brilliant but morally insensitive technocrats.

LI: Professor Wang, I don't want to criticize your proposal, but it may not be easy to test for the kinds of "moral" qualities you're looking for. 
WANG: It's not easy, but we have to try. We're not just looking for professional competence, or the ability to implement goals handed down by others. We want people who can reflect upon the deeper purposes of public policies and who give attention to the claims, real and potential, of those who might be affected by such policies. Ideally, of course, we'd select people with a certain amount of civic virtue.

LI: But it's difficult to test for those qualities in an exam. For example, people can provide you with "moral" answers, but it doesn't mean they're sincerely held or that decision makers would use them in actual situations.

WANG: Look, no system is perfect. At the very least, we could filter out morally obtuse people-for example, those who aren't even aware of the need to secure basic human rights. As well, we could eliminate political demagogues by asking questions that require people to look at both sides of controversial issues ${ }^{55}$ - most demagogues seem congenitally unable to articulate in a plausible way the kinds of arguments they hope to refute. In that sense, it's safer to rely on exams than on the democratic process. And if we're lucky, we might get some really good ones.

LI: But you can't guarantee that you'd come up with the most "moral" candidates.

WANG: [Raises voice] Of course there's no guarantee! This is politics, not philosophy. It's a question of how this system compares to the feasible alternatives; we're not searching for ironclad proofs. If you want to criticize my proposal, you have to suggest another method that's more likely to produce talented and publicspirited decision makers. ${ }^{56}$

LI: [Somewhat taken aback] Professor Wang, I guess I'm not against exams per se, it's just my concern that they should be as objective as possible. If you allow for "subjective factors" to intervene-testing for civic virtue and so on-the tests can be easily abused, with high grades being awarded on the basis of guanxi rather than merit. At least the results of our multiple-choice university entrance exams can't be skewed by personal favoritism.

WANG: I appreciate your point. At the first stage of the examination process, for reasons of efficiency I'd stick to multiple-choice exams. But after that, I think it's essential to include an essay component. I agree with you that the selection process must be seen as scrupulously fair and impartial-otherwise people won't accept the legitimacy of the House of Scholars. This isn't an insurmountable obstacle, however. The essay questions can be graded "blind," say, by a committee of experts in the field who are given scripts with numbers rather than names.

DEMO: Pardon the interruption, but wouldn't you want to interview the candidates as well? It seems to me that they should be tested for their ability to respond to oral questions. Some people are good at written exams, but they can't express themselves well or participate intelligently in a conversation with real-life individuals. This doesn't matter much if one is an academic, but it would be a serious weakness in a political ruler. And once you allow for oral interviews, you're back to Xuedong's point about potential bias in the selection process.

WANG: I agree about the need for oral interviews, but there's a neat solution to the problem of bias in oral interviews. Candidates can be interviewed behind screens, which is how musical examinations are sometimes administered. 
DEMO: But screens can't block out everything. For example, it would still be possible to identify the sex of the applicant. That might be a problem, as the female applicants could find themselves at a disadvantage. After all, only males took the civil service examinations in the past, and some people might want to maintain the "tradition" of selecting male decision makers.

WANG: Well, that's the past. East Asian countries today don't bar females from civil service examinations, and that's what I'd want for China. In fact, one of the virtues of examinations is that they're likely to increase the proportion of female decision makers. You might even get 50 percent, which is better than the Scandinavian countries! And no need to rely on an artificial and unmeritocratic quota system.

DEMO: You didn't answer my point. If you allow for oral examinations, "informal" discrimination might take place at that stage.

WANG: Perhaps voices can be processed through a kind of synthesizer that masks the sex of the respondent. Or else they can be typed on a computer screen. I'm sure there's a technical solution to this problem.

LI: Professor Li, I have another problem with "blind" examinations. If we can't actually see the respondents, it means a person with sanjiaoyan might get through. Who would trust a ruler with sanjiaoyan?

DEMO: [Interjecting] I must admit, I do not quite understand.

WANG: [Sighs] Ai ya, this is quite complicated. You see, Westerners distinguish between different eye colors-women look with envy upon Elizabeth Taylor's beautiful violet eyes; Frank Sinatra's pale blue eyes made him handsome; and so on. But Chinese people all have brown eyes, so we hardly notice eye colors, distinguishing instead between different eye shapes. The most common distinction is of course between "single" and "double" eyelids. Few Westerners notice the difference, even after being told of its relevance for Chinese people-perhaps because nearly all of you have double eyelids - but in China it's quite important to have "double" eyelids, which make the eyes look bigger and supposedly more attractive. In fact, the most common form of plastic surgery in China-and in other East Asian countries, such as Korea and Japan-is a slice above the eye to add a second eyelid.

DEMO: [With a slight twitch] Really?

WANG: It's a painless operation, far less problematic than what you call "nose jobs," not to mention the infamous silicone "treatment" debacle. In any case, what's interesting is that a rich and subtle vocabulary has evolved in Chinese to describe different eye shapes. There's a prejudice in Chinese society against "doujiyan," or "fighting-rooster eyes," but on the other hand "xingrenyan," or "almond-shaped eyes," are widely admired. I suspect that most Westerners wouldn't even notice the difference.

DEMO: This is interesting, but I'm not too sure how the topic of eye shapes fits into our discussion on "democracy with Chinese characteristics."

WANG: I was getting to that. It's not just that we've developed an aesthetic hierarchy of eye shapes. Sometimes eye shapes are said to express certain personality traits as well. For example, people with "sanjiaoyan," or triangular "three-angle" eyes, are said to be untrustworthy. That's what was worrying Xuedong-my proposal 
for "blind" grading wouldn't be able to filter out people with "sanjiaoyan," and he couldn't imagine that anyone would trust a ruler with this sort of eye shape.

LI: Thank you, Professor Wang. I should have made myself more clear.

WANG: But let me add that I wouldn't want to modify my proposal to accommodate this cultural value. On the contrary, I think we should challenge this absurd tendency to rank people on the basis of eye shapes, in the same way that we challenge other harmful traditional values and practices such as nepotism, the preference for siring male children, and the historical practice of excluding women from entry into public service. At least from a political standpoint, it's important to distinguish between desirable and undesirable cultural traits. The government should try to promote only those cultural values appropriate for the modern era, like the tradition of respect for rule by an intellectual elite.

LI: [Embarrassed] You're right, Professor Wang. I'm not an expert in the field of political philosophy, and I should have deferred to your point of view.

WANG: No need to be so modest, Xuedong. I may face these questions tomorrow at the constitutional convention, and it's important to be prepared with persuasive answers.

LI: If you'll excuse me, I must return to my studies. Nice meeting you Mr. Demo. [Li exits.]

DEMO: Perhaps I can add that American political culture is also subject to harmful prejudices. If FDR had run for president in the age of television, voters would have been aware of his physical disability, and he may have had difficulty getting elected. Many people still seem to judge political rulers on the basis of irrelevant physical characteristics.

WANG: Hence the need for "blind" evaluation of candidates for the House of Scholars.

DEMO: Let me return to the question of the content of the examinations. Even if your written examinations test for memorization, independent thought, ethics, and the ability to make good points in an actual conversation, it may still be that you're failing to test for the quality that really matters, that is, the capacity to deal with the problems of government. Don't you think it's also important to test for the ability to deal with actual political problems?

WANG: Yes, of course. Confucius himself was quite concerned with the need to identify those with know-how. He said, "A man may be able to recite the three hundred Songs; but if, when given a post in the government, he cannot turn his merits to account, or, when sent on a mission to far parts, he cannot answer particular questions, however extensive his knowledge may be, of what use is it to him?" [Analects 13.5]. In the same vein, our exams could include questions covering a wide range of actual political problems. We could ask questions about pressing issues in domestic and foreign policy, for example.

DEMO: But you'd only succeed at identifying talented generalists. And this poses certain problems. The Federal Reserve Bank, for example, is composed mainly of professional economists. More generally, conceptions of meritocracy have changed since the days of Confucius. Under conditions of modern knowledge, with its vastly 
more specialized character, it's best to identify and appoint highly trained specialists to work on policies in their particular field. Your "Confucian" exams would be quite useless for this purpose.

WANG: I'm not sure about that. Knowledge may be more specialized, but many different types of knowledge are relevant for political decisions. If anything, things are becoming more interconnected. For example, foreign policy is being driven by economic forces more than ever before: during the Asian economic crisis, we saw more of Robert Rubin than Madeleine Albright. On the other hand, it's difficult to make sense of economics without a good grasp of the underlying political forces: the World Bank was bullish about the Indonesian economy until the very end because it didn't factor in political issues like resentment against the Suharto clan or the concentration of economic wealth in the hands of the Chinese minority. So I don't think we'd want "highly trained specialists" deciding things at the very highest levels of government. What we're looking for are men and women of talent and integrity. They must be learned and sensitive to ethical considerations, as well as intellectually agile, in the sense of being able to take a "bird's-eye view" and adapt quickly to new situations in a rapidly changing modern world. Once these people are identified, it's my firm belief that they can learn to exercise wise and prudent political judgment.

DEMO: But this requires a veritable leap of faith!

WANG: I'd like to point out that what you call a "leap of faith" is already the practice in much of East Asia, and the results are quite positive overall. In Singapore, the ruling PAP favors top civil servants and ministers who have a "helicopter view," meaning that they can detach themselves from nitty-gritty details to consider matters as a whole, put issues in their overall social and political context, and anticipate the likely impact of a changing environment. Often these people have no political or technical background, but here, too, they learn to apply their wisdom to whatever problem comes up. In Hong Kong, Administrative Grade Officers-the elite unit at the apex of the civil service pyramid-are generalists; they change departments every five years or so. The assumption is that they need to be broad-minded and wide-ranging, spotting changing trends in different areas and adapting to new situations. And in Japan-like I said - the top graduates from Tokyo University's law faculty, chosen on the basis of competitive examinations, are almost automatically given important posts in the Ministry of Finance and the Ministry of International Affairs. It's simply assumed that the top academic achievers will learn "on the job."

DEMO: [Interrupting] But that "assumption" has run into problems of late. Japanese-style meritocratically chosen bureaucrats may have been an asset in the early stages of development, but they've failed quite spectacularly to provide creative solutions to the problems of an advanced economy. Just about everyone agrees there's a need for more democracy and less bureaucracy in Japan.

WANG: First of all, China is still a relatively undeveloped country, so that objection isn't relevant for China's current situation. More importantly, I'm not saying that China should copy every aspect of the Japanese model of selecting political managers. The idea is to take what has worked and avoid the rest. 
DEMO: But you're not answering my point. Even in a relatively undeveloped economy, it's better to rely on specialists than generalists. China's central bank, for example, should appoint trained economists, not generalists from the House of Scholars.

WANG: Look, I'm not arguing against the need for expertise. Of course decision makers need to rely on the views of experts, but they often need to rely on the views of different experts looking at different sides of public policy questions. Moreover, scientific "evidence" on important public policy issues is rarely conclusive. More often than not, it leaves lots of room for interpretation and judgment calls, and that's where we want decision makers of talent and integrity to come in. ${ }^{57}$ Even the Federal Reserve Bank might be better off if it included more non-economists. After all, the Fed is often accused of favoring the interests of Wall Street over Main Street, and perhaps "generalists" could make a difference.

DEMO: [Pause] Maybe you're right. And come to think of it, the use of the examination system to select "political" generalists is not unique to East Asia. In France, students compete for entry to the Ecole Nationale d'Administration, and successful graduates are subsequently empowered to make decisions in the political and business worlds, often moving back and forth between the private and public sectors. In the U.S., however, it's usually the private sector that draws on academically successful individuals with the ability to move from one domain to another and to develop the required skills "on the job." The leading business consultancy firm, McKenzie and Co., offers jobs to all Rhodes scholars who apply, no experience necessary. Investment banks like Goldman Sachs hire Ph.D.s from top universities in fields completely unrelated to banking-once again on the assumption that talent is transferable from one domain to another.

WANG: Exactly. So why shouldn't governments do the same? It would benefit society as a whole if the brightest minds were entrusted with the task of devising policies for the common good, rather than promoting the good of particular commercial enterprises. Those who succeed at rigorous and wide-ranging competitive examinations should be given the opportunity to work for the political community.

DEMO: There's another issue we need to discuss. Wouldn't you be worried about empowering people without any political experience?

WANG: I'm not saying they should immediately be given political power. Correct me if I'm wrong, but business consultants and brokers are usually trained for a year or so before they're given the power to make important decisions. I'd do the same with the House of Scholars. Once representatives are selected, they can choose an area of specialization (the top candidates get first choice) like economic policy or foreign affairs, and then they can work under the guidance of the previous batch of scholars for a transition period of a year or two. That should be enough time to get them to the point where they could make informed judgments aided by experts.

DEMO: Well, I hope you're right. But a lot seems to turn on untested hypotheses.

WANG: It's not completely untested. To repeat, this is already the practice in successful East Asian countries. However, what's distinctive-or perhaps I should say "superior" - about my proposal is that it would institutionalize the method of 
selection for political rulers, unlike the case of Japan, where de facto rulers are chosen on the basis of an informal process. And unlike "Japanese-style" competitive examinations, which are frequently criticized for placing too much weight on memorization and rewarding those who show an excessive tendency toward conformity, ${ }^{58}$ our exams would also test for independent thought and ethics. Moreover, the exercise of political power would be more transparent, compared once again with Japan, where top bureaucrats wield power in mysterious ways hidden behind the façade of democratically elected politicians. I expect that political deliberations in the House of Scholars, with the exception of debates concerning national security, would be televised and transmitted directly to the public.

\section{[The Problem of Corruption]}

DEMO: Even more important than ensuring transparency, however, is the question of accountability. And how can the representatives of the House of Scholars be held accountable if they're not subject to the electoral process? If they're given lifetime tenure, they may become arrogant, insensitive, and corrupt.

WANG: Not necessarily. Nonelected judges in the U.S. Supreme Court are given lifetime tenure, yet the Supreme Court is perhaps the least corrupt and most widely respected institution in the American political system.

DEMO: But you're proposing to give "scholar-officials" real power in the sense of the right to formulate their own policies, not just the power to enforce the Constitution.

WANG: You're right. Judges, at least in theory, have less room to maneuver than political decision makers, and it may be particularly important to institutionalize a check on the irresponsible behavior of the latter. But the electoral process is only one way of curbing power; setting term limits is another. In my view, "scholar-officials" shouldn't be given lifetime tenure, but on the other hand they must be given enough time to learn about politics and work for the long-term good. A constitutionally enshrined term limit of, say, seven or eight years seems about right.

DEMO: But how can you guarantee that "scholar-officials" would work for the common good, as opposed, say, to abusing their power for the sake of personal enrichment? If they know they'll be out of a job in seven or eight years time, they may use their period of tenure to plunder the treasury.

WANG: I am assuming, of course, that a free press will do its best to investigate and publicize incidents of corruption. Equally important, scholar-officials should be paid handsome salaries to reduce the incentive for corruption. Singapore pays the world's highest salaries to its top politicians and civil servants, and the result is an enviably low level of corruption.

DEMO: But civil servants in Singapore have a lifelong career path. What would deputies from the House of Scholars do when they retire? If they retire at the age of, say, fifty, they may turn into behind-the-scenes power brokers with the ability to deliver access in exchange for cash. 
WANG: Perhaps we can move the minimum age for deputies by five or ten years, so that a stint in the House of Scholars could be seen as the final stage in one's "career." 59 And I assume we'd pay them enough so that they wouldn't need more money after they retire. Also, I'd like to point out that this problem isn't unique to the House of Scholars: it's also a problem of how to prevent corruption and "back-door influence" ${ }^{\prime \prime}$ when elected politicians retire. I presume we'd use the same methods to prevent corruption, such as constraints on lobbying for interest groups that one dealt with as a politician. Actually, I'd worry less about deputies from the House of Scholars: the fact that they're chosen by exams and change often should make them more immune to ongoing connections with their former colleagues.

DEMO: You still seem to be placing a lot of faith in these "scholar-officials."

WANG: I don't think we should depend entirely on their honesty. I'd favor using "the stick" as well as "the carrot." Singapore, for example, imposes stiff penalties for corrupt behavior. I'm also tempted by the Republic of Venice's anticorruption strategy. That Republic, as you may know, endured for over eight centuries in the last millennium. The regime provided peace and prosperity to its citizens, had an excellent legal system, possessed an elaborate and closely observed constitution, and yet from the year 1300 onward it was legally governed by only 2 percent of its population. ${ }^{60}$ So how, you may ask, did the Republic of Venice ensure that its rulers resisted the temptation for personal enrichment? An audit was performed at the end of their tenure, and if a financial discrepancy was discovered the rulers' children were penalized. ${ }^{61}$

DEMO: The ruler's children? But what if the children were innocent?

WANG: They rarely were, and the same is true in China. The sons and daughters of government officials are notoriously corrupt, more often than not relying on their family's political connections to strike favorable deals of dubious legality. No great harm would be done by penalizing the children. On the contrary, this "Venetian" method may help to secure the honesty of officials. It may also be worth penalizing government officials for the misdeeds of their children so that public servants have an incentive to monitor the dealings of family members.

DEMO: But how can you suggest penalizing some people for the actions of others?

WANG: This may be difficult to understand. You see, the Chinese conception of the self is quite different from the typical Western view. In the West, "the buck stops" at the individual. The individual is responsible for his or her own "chosen" behavior, no more and no less. In China, by contrast, the family is typically viewed as an indissoluble organism linking ancestors and descendants into a single unit. So it's seen as quite normal for family members to be treated less as individuals than as outcomes of family and clan lineage, and thus be held responsible for the misdeeds of close relatives. No doubt family-based punishment can be cruel. In the dynastic period whole families were executed for the crimes of one member, and torture and execution included the slicing of bodies into tiny pieces and the public exposure of offenders' heads - punishments meant not to maximize pain but rather to destroy the future lives of offenders and hence end family lines. Other punishments, however, 
seem positively humane. Inspired by the best of Confucian values, some laws allowed for family members to stay in prison to care for sick relatives, and families could choose to rotate sentences among themselves, rather than impose the burden of imprisonment all upon one individual. ${ }^{62}$

DEMO: But how much of this is still relevant in the contemporary era?

WANG: I'm not saying that we should try to re-implement every one of these practices in today's society. The value of family-based responsibility, however, is still very much with us in the Chinese world. One of the most painful aspects of our experience with "communism" is that people were frequently punished for the "counterrevolutionary" acts of family members. Some of my friends were persecuted simply on the grounds that distant relatives had "bourgeois" backgrounds. And let's not mention the distasteful practice of charging families for the cost of bullets used to execute their relatives.

DEMO: As you say, these were "painful" experiences. So doesn't it follow that contemporary Chinese should challenge, rather than affirm, the traditional value of family-based punishment?

WANG: Yes, but my point is that the conception of the family as a single unit of responsibility can also serve to justify certain policies designed to address contemporary problems. You're familiar, for example, with China's overpopulation crisis. The Communists tried to improve the situation by implementing a one-childper-family policy, which in practice meant that second children faced limited educational opportunities compared to firstborns. One might say that they were "punished" for the misdeeds of their parents. This might seem unjust given Western conceptions of individual responsibility, but most Chinese-or in any case, most urban intellectuals ${ }^{63}$ - support the one-child-per-family policy, as well as its publicly affirmed practical consequences.

DEMO: Come to think of it, the value of family-based responsibility also plays a role in legitimizing some policies in the U.S. Some states withhold welfare payments from single mothers, and their children often pay the price. Voters in California supported Proposition 187, which punished the children of illegal immigrants by barring them from public schools. At one time the Clinton Administration punished foreign companies operating in Cuba by barring both executives and their children from visiting or studying in the U.S. ${ }^{64}$ There have also been proposals to punish parents for the misdeeds of their children as a means of reducing juvenile delinquency. I must admit, however, that I feel uncomfortable with such policies.

WANG: So do I. Family-based punishment can easily be abused. But the problem of corruption is so serious in China-and much can be traced to the misuses of family connections in political circles - that I think it's worth thinking about the possibility of invoking family-based punishment as a means of minimizing corruption in the political system. I hope I'm wrong, however. If term limits work out in practice, and if a combination of publicity, public deliberations, high salaries, and harsh penalties directed solely at the perpetrator of financial misdeeds can successfully reduce corruption to a tolerable level, then family-based punishments may not be necessary. They should only be employed as a last resort. ${ }^{65}$ 


\section{[The Question of Universalizability]}

DEMO: [Pause] Let's assume for the sake of argument that your proposal for a House of Scholars does indeed fulfill your expectations. It's composed of persons with the potential to act as "guardians" of virtue and knowledge governing in the interests of the common good, while various constitutional and anticorruption devices serve to curb the tendency to abuse power. Let's assume as well that this system of "rule by an intellectual elite" is particularly appropriate for addressing the increasingly complex and inter-linked political problems of modern societies. Now let me ask you the following question. Why do you seem to think that the House of Scholars proposal is only appropriate for China? Why shouldn't it be adopted by the political systems of all modern and modernizing societies?

WANG: I suspect that my proposal would be laughed out of existence in certain contexts. It seems appropriate in a Chinese context where most twentieth-century pro-democracy movements were initiated and carried out by the intellectual elite. ${ }^{66}$ They weren't campaigning for pure democratic rule, but rather for "people's rule" constrained by the wisdom of a public-spirited intellectual elite. In other contexts, however, different groups played a greater role in democratization movements, and a "House of Scholars" may not satisfy their aspirations. Equally important, the House of Scholars can seem legitimate in the eyes of those Chinese people "on the bottom," because of our tradition of respect for meritocratically chosen scholar-officials. But things are different elsewhere. Think of the United States, with its deeply rooted antiintellectualism, its tradition of popular resentment against "pointy-headed" intellectuals. When I'm in East Asian societies built on a foundation of Confucian ideals, and I tell taxi drivers I'm a professor of political philosophy, they almost invariably ask for my views on the burning political issues of the day. ${ }^{67}$ In the U.S., they typically scoff and proceed to inform me that I know nothing about the "real world." So I doubt that a House of Scholars could ever achieve much popular legitimacy in the U.S.

DEMO: But there's more than one side to American popular culture. You yourself pointed out that the U.S Supreme Court-composed largely of brilliant academic overachievers-may be the most respected institution in the American political system. And, come to think of it, at least one leading American intellectual has floated a proposal not altogether dissimilar from your own. Are you familiar with Daniel Bell? WANG: You mean the distinguished American sociologist?

DEMO: Of course. About ten years ago Bell developed a highly imaginative proposal for political reform of the U.S. Congress. The main problem with this institution, as you may know, is that its members, particularly in the House of Representatives, are constantly scrambling to raise money for reelection, leading to the impression, if not the reality, that politicians are primarily beholden to financial interests instead of being committed to promoting the common good. So to "relegitimize" the Congress in the eyes of the American public, Bell proposed setting a term limit for members of Congress-three terms for senators, and four terms of four (rather than two) years for representatives. Then retirees would be recruited into a 
"third chamber," whose pension plus an additional income would give them financial security. This "House of Counselors," as Bell puts it, would be the pool for the commissions and independent bodies that evaluate policy and advise the government. The country would thus have a group of experienced and disinterested individuals ready to act for the common good, backed by a certain degree of popular support. ${ }^{68}$ I remember Bell's proposal well because my organization came close to endorsing the "House of Counselors" proposal a couple of years ago. We thought it was a better idea than, say, having the president's wife devise plans for long-term health-care policy.

WANG: I don't fully understand the American political system, but wouldn't the implementation of this proposal require fairly radical changes in the U.S. Constitution?

DEMO: Yes, that's one reason we finally decided not to go along. But who knows, Bell's idea may come to fruition one day if the Congress continues to lose the trust of the American public.

WANG: [Short pause] Bell's idea is actually quite different from what I have in mind. The "House of Counselors" may still be composed of mediocre people whose sole qualification is that they succeeded in getting elected to Congress. I'm after truly disinterested men and women of talent who haven't had to demean themselves by pandering to the rich and powerful, or to the short-term concerns of the public. A closer "Western" analog, though in a somewhat watered-down form, is the House of Lords in the U.K.

DEMO: [Surprised] The House of Lords!

WANG: Yes. Contrary to popular belief, the House of Lords still has considerable impact on legislation. It has the power to delay bills passed by the House of Commons for one year, though it rarely exercises this power. More commonly, it operates as a revising body, refining bills from the lower chamber by filling in the details and closing the loopholes. And, from what I hear, it performs that task with admirable competence and nonpartisanship. Its debates are elegant, non-adversarial, and informative, and they sometimes lead to significant amendments. Many of its members have a depth of expertise from earlier careers that's often lacking in the relative youngsters occupying the House of Commons. ${ }^{69}$

DEMO: But it includes hereditary peers, who inherit the right to sit there and vote on legislation simply on the basis of their aristocratic ancestry. That's not what you want for your House of Scholars, is it?

WANG: Of course not. But didn't Blair's Labour government get rid of hereditary peers? ${ }^{70}$ Other peers are appointed by the Queen on the recommendation of the prime minister, and this seems to be a relatively meritocratic process. The respected political philosopher Raymond Plant, for example, is a member of the House of Lords. But you're right, it should be reformed and made into a truly meritocratic body. If it were up to me, I'd convert it into a House of Scholars, composed of representatives selected on the basis of competitive examinations.

DEMO: Maybe your proposal is most appropriate for the United Kingdom?

WANG: I doubt it. There isn't a cultural base of support for a House of Scholars in 
the United Kingdom. ${ }^{71}$ Of course there's an English tradition of deference to one's "betters," but the meritocratic idea of "rule of the best" is tainted with notions of property and class privilege in a way that hasn't been true in Confucian-influenced East Asia. I'm suspicious of sentimental readings of history, but, generally speaking, you did have a fair and open examination process in Confucian societies, and examinations have often been seen as a vehicle for upward mobility. ${ }^{72}$

DEMO: In that case, why not recommend a House of Scholars for Korea, Japan, Singapore, and Taiwan? You've already said, for example, that your proposal compensates for flaws in the Japanese system of de facto rule by powerful bureaucrats, such as the lack of transparency and accountability, so why shouldn't a House of Scholars be appropriate for Japan?

WANG: Maybe one day other East Asian societies will be attracted by my proposal. If the political status quo isn't seen to be working well, it might be the right time to propose this kind of change. ${ }^{73}$ In China there's an obvious need for serious political reform, and people seem to be quite receptive to new political ideas.

DEMO: [Pause] I'm slowly coming around to your view. Perhaps I can ask you a couple more questions, if you don't mind. I realize I've been suggesting that you should consider expanding the scope of your proposal to countries other than China, but now let me suggest that you're being too ambitious by proposing to apply the House of Scholars idea to the whole of China. China, as you know, is not a culturally homogeneous entity. This means, for one thing, that non-Han Chinese minority groups may not identify with a Confucian tradition of rule by a meritocratically selected political elite, and it seems unfair to ask them to participate in your scheme.

WANG: I have no objections to granting substantial self-administration to minority areas like Tibet and Xinjiang. With respect to the House of Scholars, minority groups can be guaranteed a certain number of seats. Hong Kong can also be given a seat, and Taiwan, if it agrees to join, can be given three or four seats. ${ }^{74}$

DEMO: My point is that the practice of competition for political office on the basis of written examinations may seem "foreign" to some non-Han Chinese groups, and they may not support this method of selecting political rulers.

WANG: There are ways to accommodate the cultural particularities of minority groups. Minorities can choose a different selection process for their deputies. Or they can modify the content of examinations to better reflect their own traditions; for example, the examination for Tibetan representatives can include a component on Buddhism and the Tibetan language. These are details to be worked out at tomorrow's convention.

\section{[The Problem of Gridlock]}

DEMO: [Pause] One last question. So far we've only been talking about the upper house in your proposed bicameral legislature. The lower house, you said, should be composed of democratically elected representatives. But the two houses may not always agree on the same policies.

WANG: Of course. 
DEMO: So my question is the following: how would you resolve disputes between the lower house and the upper house? Is there a mechanism to break gridlock between the two houses of government?

WANG: A tough question. But the answer ultimately depends on which of the two houses has more power. Proponents of rule by a meritocratic elite-let's call them "Confucians" —would want to empower the House of Scholars.

DEMO: If you really want to be a Confucian, then you'd want the top power broker to be an Emperor, who stands above the fray. After all, the Head of State in traditional China was a "divinely appointed" Sage-King, and meritocratically selected civil servants had the role of advising, and perhaps admonishing, but they weren't the top decision makers. So why not try to resurrect the monarchic Chinese tradition?

WANG: [Laughs] Don't be silly. That would never work: it's difficult, if not impossible, to resurrect a monarchical system that's been dead for nearly a century. It's not like you can make people believe in a "divinely appointed" ruler who emerges from a constitutional convention. And besides, nobody's pushing for that system now. What's more realistic, I think, is to select the Head of State from the House of Scholars. Perhaps it can be the eldest member, or if you really want to be meritocratic it can go to the top achiever in the examinations. What's your advice?

DEMO: To be frank, I don't like either option. In my opinion, the House of Scholars should be constitutionally subordinate to the democratic lower house. Like Bell's House of Counselors, it could be the pool for the commissions and independent bodies that evaluate policy and advise the government. Like the House of Lords, it could play the relatively minor role of revising legislation passed on from the lower house, pointing out flaws and proposing small amendments. I don't mind if a "symbolic," largely ceremonial, Head of State comes from the House of Scholars, but the Head of Government-the one who really makes the political decisionsshould come from the lower house. And so should the important ministers.

WANG: [Face whitens] But, but, I thought you were on my side!

DEMO: I am! Like I said, I'm not against a House of Scholars. I agree with your point that it seems to suit China's political culture and that it's better than alternative mechanisms for institutionalizing rule by an intellectual elite. But I can only go so far. I can't endorse a political system that gives unelected leaders the power to make final decisions. Elected politicians can-and should-rely on the advice of talented and disinterested individuals, but "the people's" chosen leaders should hold the ultimate trump cards.

WANG: But that would be a disaster in China! Democrats in the lower houseconcerned primarily about the next election and heavily influenced by commercial interests-may favor rapid economic growth regardless of the long-term ecological consequences, whereas deputies in the House of Scholars-who arrive at their decisions following careful, nonpartisan deliberations, unconstrained by the need to accommodate particular interests-may opt for slower, ecologically sustainable development without the same immediate material benefits. Who should win? The democrats? 
DEMO: It's hard to answer in the abstract. Policy disputes tend to be more concrete than that.

WANG: O.K., let's take the example of the one-child-per-family policy. Most peasants oppose this policy, partly due to the deeply held rural preference for siring male children. Those views would probably dominate the lower house-the large majority of Chinese still live in the countryside - and the democrats may well vote to repeal this policy, whatever the long-term consequences. But a House of Scholarsdominated by intellectuals, most of whom understand the need for this policy ${ }^{75}$ would probably vote to uphold it. And you think the democrats should get their way?

DEMO: You're presenting this as an "either-or" issue: the vulgar democrats versus the reflective "meritocrats." But surely some meritocrats will side with the democrats in the lower house. Even if they're completely selfless, meritocrats won't necessarily converge on the same interpretation of the common good.

WANG: Of course. ${ }^{76}$ But conflicts can be resolved by majority decision making, and the question is what to do when a majority in the upper house is opposed by a majority in the lower house. I'd favor-for example-a constitutional formula providing supermajorities in the House of Scholars with the right to override majorities in the lower house.

DEMO: [Raises voice] Well, I'd favor the opposite. And I doubt most Chinese would go along with a system that's designed to systematically override the wishes of the leaders they choose to represent their own interests! It's not like you're asking them to endorse an institution like the Supreme Court, which has carefully circumscribed powers. They're supposed to accept an institution that has overriding power, in principle, over all the decisions of democratically elected leaders!

WANG: [Short pause] Mmm, yes, you have a point. It would be hard to sell that part. $^{77}$

DEMO: And you don't have to! Even a constitutionally subordinate upper house could play an important role in China. The country would have a group of relatively talented and disinterested individuals adding wisdom and long-term planning to the decision-making process. And if the House is legitimate in the "eyes of the people" - which is quite likely in a society with a tradition of respect for a meritocratically chosen political elite-the House of Scholars can exercise a great deal of moral authority. Democratic majorities would find it hard to ignore the points of view that emerge from open deliberation among deputies in the House of Scholars. At the very least, politicians in the lower house who systematically disregard policy recommendations of the House of Scholars may find it difficult to get reelected. ${ }^{78}$ What I'm trying to say is that you don't need much constitutional support to have a powerful House of Scholars!

\section{[Implementation of the Proposal]}

WANG: [Pause] Yes, you may be right. I guess I'd be satisfied with a constitutionally subordinate House of Scholars. The important point is that the House's decisions have real, practical impact in the political arena. 
DEMO: Well, that would also depend on other factors, such as the relationship between the House of Scholars and the judiciary. ${ }^{79}$

WANG: Of course. There are many such "details" to be ironed out during the course of deliberations at the constitutional convention. ${ }^{80}$ First, however, I have to deal with a more immediate problem. I'm really worried about the possibility that I won't get enough votes for a House of Scholars, even one with minimal powers. The Communists-or the "Liberal Democrats," as they now prefer to call themselvesfavor the electoral process, and they have no interest in a House of Scholars. They learned from the Russian case that their pervasive bureaucratic apparatus could easily be converted into a powerful electoral machinery. The ex-dissidents, especially the younger ones, also favor a powerful, democratically elected legislature. They're quite sure they can get elected, following in the footsteps of the Mandelas and the Havels. I don't blame them, mind you. I've always admired their courage over the years, and I think they deserve political payback of some kind or other. But meanwhile I have to deal with the fact that it's not in the interest of any of the major political forces to support my proposal. The only weapon I have at my disposal is rational argumentation.

DEMO: [Smiles] That's not very promising, is it?

WANG: No. This is real politics, unfortunately-not an academic seminar. Still, not all is lost. I think I can get some support from the women's groups: they like the idea of examinations that will have the effect of increasing the proportion of women in the political process. And there's one Marxist delegate-perhaps the only genuine Marxist in China-who may go along, because he's worried about the possibility that a democratically elected legislature will be captured by big business interests.

DEMO: That's it?

WANG: Well, I have to try to get more support from the democrats. If all else fails, I have one final argument up my sleeve: the "lesson" of Russia's transition to democracy. After the Soviet Union disintegrated, Russians were confronted with a stark choice: either communist stagnation, or progress in the form of Western-style political practices. They might have gone along for a while if democracy had delivered material goods and provided social peace. But things didn't go according to plan, and not surprisingly it turned out that Western-style democracy had fairly shallow roots in the country. Can we really blame the Russian people? It's humiliating for a people-especially if they feel part of an old and proud civilization-to jettison the past as a whole, to be told that nothing valuable can be found in their national political history. So when things go wrong, when democracy fails to meet people's aspirations, the temptation will be to turn to a strongman who promises to restore national pride. But all this can be avoided if a democratic system incorporates an element of traditional political culture. Citizens will bear with the system even when things go wrong, and they can't put all the blame on the evil machinations of foreigners.

DEMO: So what you're saying is that Russian democracy was unstable because no serious effort was made to incorporate traditional political characteristics into their political system. ${ }^{81}$ To avoid this mistake in the case of China, you're offering a 
middle way between Confucianism and Western democracy, a "democracy with Chinese characteristics."

WANG: Exactly. A House of Scholars designed to restrain democratic majorities can also have the paradoxical effect of securing a democratic system in China. Now let me ask you a question, if I may. I think it would help my case tomorrow if I can tell the delegates that your organization supports my proposal, at least the general idea of a bicameral legislature with a House of Scholars. I suspect that some of the "radical democrats" will try to portray my scheme as a reactionary plot concocted by sinister authoritarian forces....

DEMO: [Interrupting] But that's ridiculous.

WANG: I know, but some of the younger ones are quite dogmatic; they won't even contemplate the possibility of a middle ground between traditional Chinese values and Western democracy. And for my proposal to pass even in its mildest form, I have to respond to all forms of criticism in an effective way. So if I say that even the U.S.-based National Council for Democracy endorses my proposal, this can help to undercut the arguments of "radical democrats."

DEMO: Like I said, I can go along if the House of Scholars is constitutionally subordinate to the lower, democratic house.

WANG: Fair enough.

DEMO: It's also in your interest to emphasize this part: you'd probably get more votes from the democrats if you make it explicit that the lower house has the ultimate say.

WANG: Yes, good point. I think I'll do that.

[At this point, PROFESSOR WANG gets up, and walks toward the wooden statue of Confucius in the far corner of his office. DEMO watches in amazement as PROFESSOR WANG gently unscrews Confucius' head, revealing a tray with a bottle of wuliangye and two small porcelain cups.]

WANG: [Filling the cups] This, my friend, is high-quality stuff.

DEMO: And potent, too?

WANG: Yes, but my motivation is the pursuit of quality, not power.

DEMO: It's nice to have both, wouldn't you say?

WANG: [Handing DEMO a cup] I won't deny that. But let's move on to more serious matters.

DEMO: I agree. A toast to cross-cultural friendship. Ganbei!

WANG: Ganbei!

Notes

Earlier versions of this article were presented as papers at the "The First Asia Symposium in Jurisprudence: Law in a Changing World," held at Tokyo University, October 1996; at a conference on "Human Rights and East Asia," held at the University of Hong Kong, December 1996; and at a workshop on "Confucianism and Democracy," held in Jirae, Korea, June 1998. I am grateful for the audiences' ques- 
tions and comments. I would also like to thank Daniel Bell (the distinguished American sociologist), Joseph Chan, Robert Dahl, Michael Davis, Laurence Goldstein, Chad Hansen, Hahm Chaibong, Inoue Tatsuo, Joe Lau, Stephen Macedo, Masa Okano, Onuma Yasuaki, Thomas Pogge, Eugene Qian, Song Bing, Wang Hao, Yasuda Nobuyuki, and three anonymous referees for their comments and criticisms. I owe special thanks to Roger Ames, for being open to the dialogue form and to Andrew Nathan, for his detailed written comments. I owe most to Michael Walzer, who first inspired this proposal with the following comment, from Thick and Thin (Notre Dame: University of Notre Dame Press, 1994), pp. 59-60:

I recognized in the arguments of the students [in Tiananmen Square in 1989] a sense of their mission or their special political role that was clearly incompatible with the American [democratic] ideal (in which a certain hostility to the claims of the educated classes has always been present) and probably incompatible too with the prevailing abstract and universal theories. Student elitism was rooted, perhaps, in Leninist vanguard politics or, more likely, in pre-communist cultural traditions (Confucian, mandarin) specific to China and certain to show up in any version of Chinese democracy.

I asked myself, "what might this mean in practice?" and the result is this essay in drama form. I would also like to thank Walzer for his written comments on the final product.

1 - While most of the contributors to a symposium addressing the question "Will China Democratize?" "find themselves unable to identify any groups that are sufficiently powerful, motivated, and aligned to produce the democratic changes that supposedly are inevitable," Andrew Nathan notes that "several contributors acknowledge China's history of surprising political eruptions and breakthroughs, and point to the ever-present possibility of surprises" (Nathan, "Even Our Caution Must Be Hedged," Journal of Democracy 9 [1] [January 1998]: 62, 63-64).

2 - See, for example, "Beijing Spring," Far Eastern Economic Review, 2 April 1998, pp. 20-22. Two periodicals-Reform Magazine and ResPublica-have published articles calling for democratic reform. ResPublica published a Chineselanguage translation of a short piece that presents this idea for a bicameral legislature with an upper House of Scholars ("A Confucian Democracy for the 21st Century," ResPublica 4 (1997), pp. 378-392). The English version was published in Law in a Changing World: Asian Alternatives, ed. Morigiwa Yasutomo, Archiv fuer Rechts- und Sozialphilosophie, Beiheft 72 (Stuttgart: Franz Steiner Verlag, 1972), pp. 37-49.

3 - Some observers did in fact predict this event. In 1986 Emmanuel Todd of the Paris National Institute for Demographic Research predicted "with clinical precision that the Soviet Union would soon disintegrate" (see Erazim Kohak, "The Search for Europe," Dissent, Spring 1996, p. 15). Peter Frank of the University of Essex also predicted some of the events in the early 1990s along with their causes. But the more important point is that most political thinkers were 
still working within the "realist" paradigm of how to deal with communist-type institutions at the time the Soviet empire collapsed instead of thinking in concrete terms about what should come after communism, with the consequence that the options were narrowed to a choice between Western-style democracy and a "return to communism" (see the subsection below on "Implementation of the Proposal").

4 - See, for example, Yan Jiaqi, Toward a Democratic China (Honolulu: University of Hawai'i Press, 1989), chap. 17; Andrew Nathan, Chinese Democracy (London: Tauris, 1986), p. 127; Orville Schell, Discos and Democracy (New York: Pantheon, 1988), p. 198.

5 - Even some American "communitarians" tend to argue along these lines (i.e., community is seen as a means for liberty): see, for example, Benjamin Barber, "A Mandate for Liberty: Requiring Education-Based Community Service," in Rights and the Common Good, ed. Amitai Etzioni (New York: St. Martin's Press, 1995), p. 194.

6 - The Federal Reserve Board also has direct influence on countries that peg their currencies to the U.S. dollar. As the Hong Kong Monetary Authority chief executive Joseph Yam Chi-kwong (the highest-paid civil servant in Hong Kong) put it, "The cost of operating a fixed exchange rate system is that you have conceded your sovereign right over monetary policy to the central bank of the currency to which you are linked. In our case it is Alan Greenspan [U.S. Federal Reserve chairman] who determines monetary policy for us" (Peter Seidlitz and David Murphy, "Yam Calls for Asian Facility to End Crisis," South China Morning Post, 14 June 1998, Money section, p. 4). The German Bundesbank is arguably even more powerful, with the power to affect monetary policy in several European countries. It is also worth noting that the new British Labour government has empowered the U.K. Central Bank to set interest rates, on the grounds, as the chancellor of the Exchequer explained, that "politicians far too often [had been] setting policy to suit their needs, with the result that the British economy had been plagued by damaging cycles" (Erik Ibsen, "Labour Empowers U.K. Central Bank to Set Interest Rate," International Herald Tribune, 7 May 1997, p. 10).

7 - See, for example, John Cassidy, "Fleeing the Fed," New Yorker, 19 February 1996, pp. 45-46. The title of this article refers to Alan Blinder, who is supposed to have "fled the Fed" due to differences over the lack of transparency and accountability at the central bank, but it is interesting to note that Blinder has nonetheless written an article extolling the virtues of the Fed and arguing for the need to extend such "apolitical" decision-making bodies to other domains (Blinder, "Is Government Too Political?" Foreign Affairs 6 [4] [November/ December 1997]: 115-126). "At the Federal Reserve," Blinder says,

[p]olicy discussions are serious, even somber, and disagreements are almost always over a policy's economic, social, or legal merits, not its political marketability. Overtly 
partisan talk is deemed not just inappropriate, but ill-mannered. The attitudes of particular legislators, interest groups, or political parties toward monetary policy are rarely mentioned, for they are considered irrelevant. And the Fed rarely discusses its "message." The Fed does not always make the right call, but its criteria are clearly apolitical. And its decisions are arguably better, on average, than those made in the political cauldron. (p. 117)

Blinder adds that "what justifies assigning so much power to a small group of unelected officials" is the fact that monetary policy requires complex technical judgments best made by trained specialists and (most important) the fact that good policy decisions require patience, a long time horizon, and (sometimes) short-term pain-qualities not normally associated with "short-sighted politicians with their eyes on elections" —and these same arguments apply "just as forcefully to many other areas of government policy," such as "health policy (should we spend more on cancer or AIDS research?), tax policy (should we reduce taxes on capital gains?), or environmental policy (how should we cope with damage to the ozone layer?)" (p. 118).

The main problem with Blinder's article is that he conflates nonpartisan decision making with value-free technocratic decision making, which could not be further from the truth. He argues that "value judgements should be made democratically by elected officials [and] appointed professionals would design the means to achieve those ends, presumably choosing them on nonpartisan, technocratic grounds" (p. 124), though he does seem to be aware of counterarguments (p. 126). In fact, decision-making bodies such as the Fed cannot avoid making value judgments (e.g., who benefits and who loses from monetary policy), and part of the justification for insulating these bodies from the decisions of elected politicians is precisely the fact (hope?) that they can make better decisions than politicians from a moral point of view-for example, by doing more to consider the interests of minorities, future generations, foreigners, and others affected by their policies. (On the need "to give attention to the claims of everyone who might be affected by their political actions," see Amy Gutmann and Dennis Thompson, Democracy and Disagreement [Cambridge: Harvard University Press, 1996], p. 227 and chaps. 4 and 6. Gutmann and Thompson, however, seem to place too much faith in the ability and willingness of elected politicians to look after the interests of non-constituents; see my chapter "Implementing Deliberative Democracy in East Asia," in Stephen Macedo's edited book Deliberative Politics: Essays on Democracy and Disagreement [New York: Oxford University Press, 1999], pp. 70-87).

8 - Ronald Dworkin suggests that the "anti-majoritarian" Supreme Court is democratic (as opposed to acting as a constraint on the decisions of elected politicians), not simply because ultimately the people could override a Court decision by amending the Constitution, but also because people realize that the majority needs to be restrained in certain circumstances and so support the Supreme Court and its role as constitutional watchdog (Dworkin, Freedom's 
Law [Cambridge: Harvard University Press, 1996], p. 16). Dworkin can make this move because he defines democracy not as decision making by elected politicians but rather as decision making that treats "all members of the community, as individuals, with equal concern and respect," but he provides no reason for the argument that this "alternate account of the aim of democracy ... [d] emands much the same structure of government as the majoritarian premise does" (p. 17) if less-than-democratic institutions composed of unelected decision makers such as the House of Scholars can feasibly do a better job at treating people with equal concern and respect compared to political institutions composed of elected politicians. In my view, Dworkin should "come clean" and admit that he is really talking about justice, not democracy, and that (like Wang and Alan Blinder) he would favor more constraints on the powers of democratically elected politicians if this can achieve the end of securing more justice.

9 - Consider the following reflections by Robert Reich, the U.S. Secretary of Labor from 1992 to 1996: "only he [Alan Greenspan, the chief of the U.S. Federal Reserve Bank] has the power to raise or lower short-term interest rates. Like Paul Volcker, the Fed chief before him, Greenspan can put the economy in a tailspin simply by tightening his grip. Volcker did it in 1979, and Jimmy Carter was fired. Bill Clinton knows that. Greenspan has the most important grip in town: Bill's balls, in the palm of his hand" (Reich, "Locked in the Cabinet," New Yorker, 21 April 1997, pp. 44-45).

10 - See, for example, Karel Van Wolferen, The Enigma of Japanese Power (London: Macmillan, 1989).

11 - See, for example, Benjamin Fulford, "Japan's Reluctant Reformers Basking in the Status Quo," South China Morning Post, 7 July 1998, Business section, p. 5. For a book-length indictment of the Ministry of Finance's failures from the late 1980s to the late 1990s, see Peter Hartcher, The Ministry: How Japan's Most Powerful Institution Endangers World Markets (Boston: Harvard Business School Press, 1998).

12 - See Sheryl WuDunn, "Japan's Bureaucrats Fumble away the Traditional Center of Power," International Herald Tribune, 7 May 1996, p. 4.

13 - Unless otherwise indicated, I rely on Arthur Waley's translation, The Analects of Confucius (London: Allen and Unwin, 1938).

14 - According to Bruce Brooks, however, the person we refer to as "Confucius" was probably directly responsible only for the ideas expressed in Book 4 of the Analects, and an interest in the well-being of the populace does not appear until Book 12, which may date to more than 150 years after the death of Confucius (Brooks, The Original Analects [New York: Columbia University Press, 1997]; I thank Chris Fraser for bringing this reference to my attention). Whatever the truth of this argument, the fact remains that the dominant interpretation 
of Confucianism transmitted over the past two thousand years has valued public service as the highest of life's achievements.

15 - It is worth noting, however, that many aspiring scholar-officials opted for Daoism only after they failed the civil service examinations, which suggests that public service would have been their first choice.

16 - See Merle Goldman, "Politically Engaged Intellectuals in the Deng-Jiang Era: A Changing Relationship with the Party-State," China Quarterly, 1996, p. 38.

17 - When we think about the (un)likelihood of the "American" equivalent-a few dozen students from Harvard and MIT leading a massive movement for social change with the enthusiastic support and participation of a million workingclass Bostonians - it becomes clear just how distinctive the Chinese value of respect for rule by an intellectual elite really seems to be.

18 - As Tu Wei-ming puts it, "the Confucian scholar-official mentality still functions in the psychocultural construct of East Asian societies" (see Tu's edited book Confucian Traditions in East Asian Modernity [Cambridge: Harvard University Press, 1996], p. 15. See also Ronald Dore, "Elitism and Democracy," La Revue Tocqueville/The Tocqueville Review 14 [2] [1993]: p. 70).

19 - See Jean-Jacques Rousseau, The Confessions, trans. J. M. Cohen (Harmondsworth, England: Penguin, 1953), pp. 327-328.

20 - See Michael Hill and Lian Kwen Fee, The Politics of Nation Building and Citizenship in Singapore (London: Routledge, 1995), p. 192.

21 - See "Village Committees: The Link between Economic and Political Reform," China Development Briefing, issue 4 (January 1997): 18-20.

22 - According to Vivienne Shue, democracy movement leaders such as Fang Lizhi "have expressed only horror at a democratic formula that would give equal voting rights to peasants" ("China: Transition Postponed?" Problems of Communism, January-April 1992, p. 163). In a recent survey of proposals for political reform in China, Andrew Nathan notes that he is "not aware of any proposal to move to one-man-one-vote." The possibility of a farmer-dominated legislature has led some reformers to endorse the current system of malapportionment, which favors urban over rural voters ("China's Constitutionalist Option," Journal of Democracy 7 [4] [October 1996]: 48).

23 - See "A Conversation with Lee Kuan Yew," Foreign Affairs, March/April 1994, and the Straits Times (Singapore), 30 July 1994.

24 - See John Stuart Mill, "Considerations on Representative Government," in Three Essays (Oxford: Oxford University Press, 1975), chap. 8.

25 - See Richard Arneson, "Democratic Rights at National and Workplace Levels," in David Copp, Jean Hampton, and John Roemer, eds., The Idea of Democracy (Cambridge: Cambridge University Press, 1993), p. 137. 
26 - I thank Joe Lau for this point.

27 - See G. W. F. Hegel, Elements of the Philosophy of Right, ed. Allen Wood, trans. H. B. Nisbet (Cambridge: Cambridge University Press, 1991).

28 - See Steven Smith, Hegel's Critique of Liberalism (Chicago: University of Chicago Press, 1989), p. 142.

29 - On Hegel's conception of freedom, see Charles Taylor, Hegel and Modern Society (Cambridge: Cambridge University Press, 1979).

30 - According to Steven Smith, however, Hegel's form of liberal corporatism is "probably closest to the contemporary experiences of Scandinavia, France, and Britain, with their highly structured relations between interest organizations and administrative bodies" (Hegel's Critique of Liberalism, p. 145). But Western European-style "corporatism" still includes a house of government composed of representatives elected by individuals rather than groups.

31 - The post-handover authorities slashed the number of eligible voters for functional constituencies by 2.5 million (the last British Governor of Hong Kong, Chris Patten, had broadened the groupings of most constituencies to include ordinary employees), but it is interesting to note that the "democrats" did not always favor widening the electorate for the functional constituencies: when the "pro-China" DAB proposed amending the social welfare functional constituency to include kaifong associations and other nonprofit providers of social services, they were opposed by the democrats, apparently because these new groups were less inclined to vote for them. More generally, "political parties were acting out of naked self-interest by introducing amendments [altering the composition of the functional constituencies] to boost their power" ("Poll Change Approved," South China Morning Post, 28 September 1997, p. 1). This suggests that it is difficult, if not impossible, to determine the composition of eligible voters for functional constituencies (and to draw the line between functional constituencies) in a way that avoids political controversy and avoids undermining the moral credibility of a "corporatist" legislature. To be fair to the democrats, however, they favor scrapping the whole functional-constituency system in favor of a one-person-one-vote legislature.

32 - See Norman Miners, The Government and Politics of Hong Kong, 5th ed. (Hong Kong: Oxford University Press, 1995), pp. 111-117.

33 - See John Stuart Mill, "On Liberty," in Three Essays (Oxford: Oxford University Press, 1975), p. 28.

34 - See, for example, "A Censor Accuses a Eunuch," in Patricia Buckley Ebrey, ed., Chinese Civilization: A Sourcebook, 2d ed. (New York: Free Press, 1993), pp. 263-266.

35 - See my article, "A Communitarian Critique of Authoritarianism: The Case of Singapore," Political Theory 25 (1) (February 1997), esp. pp. 9-16. 
36 - Miners, The Government and Politics of Hong Kong, pp. 117-118.

37 - "Lone Voice in a Tame Wilderness," South China Morning Post, 17 May 1998, p. 11.

38 - See D. C. Lau's translation, The Analects (London: Penguin, 1979), p. 74.

39 - See Joseph Chan, "A Confucian Perspective on Human Rights," in Joanne Bauer and Daniel A. Bell, eds., The East Asian Challenge for Human Rights (New York: Cambridge University Press, 1999), pp. 212-240.

40 - Mencius, "On Government," in Ebrey, Chinese Civilization: A Sourcebook, p. 23. However, it is also possible to interpret this passage to mean that "the fellow Zhou" deserved to have his head cut off not because he didn't serve the people but because he was a bad person in a way that mattered to Mencius. "The people," in other words, may not have been the source of legitimacy in Mencius, but only its beneficiary and perhaps an operational indicator of its presence or absence (I thank Andrew Nathan for this point).

41 - For an account of the "dark side" of Confucianism, see Ci Jiwei, "The Right, the Good, and Rights" (paper presented at a conference on "Confucianism and Human Rights," Beijing University, June 1998).

42 - See the Basic Writings of Han Fei Tzu, trans. Burton Watson (New York: Columbia University Press, 1967), p. 108.

43 - Similar provisions exist in contemporary Korea. For example, article 155 of the Criminal Law "guarantees exemption from punishment for the crimes of suppression of evidence, concealment and forgery or alteration of the evidence in criminal cases if such acts were committed by a relative, head of the house, or a family member living with the said person, for the benefit of the criminal." While such laws "may be explained as a means of securing a fair trial, they could also be explained as remnants of Confucian family ethics which protect the intimacy of family relations" (Oh Byung-Sun, "Cultural Values and Human Rights: The Korean Perspective," in Jefferson R. Plantilla and Sebasti L. Raj, SJ, eds., Human Rights in Asian Cultures: Continuity and Change [Osaka: Hurights Osaka, 1997], p. 235).

44 - See Derk Bodde and Clarence Morris, Law in Imperial China (Cambridge: Harvard University Press, 1967), p. 40.

45 - See Albert Chen, "Confucian Legal Culture and Its Modern Fate" (unpublished manuscript), p. 17.

46 - This is not to suggest that each Confuciann value, taken by itself, can encourage disobedience and foster a critical spirit: for example, an ethic of filial piety will not breed a critical spirit if the ruler does not require a person to act wrongly toward his or her parents (I thank Michael Walzer for this point). But, taken together with other values-such as Mencius' idea that the use of force is justified to overthrow an emperor who has violated the "Heavenly Mandate"; 
the ruler's obligation to provide for the welfare of the people above all else; the idea that conformity to norms and rituals must come "from inside" (see Philip J. Ivanhoe, Confucian Moral Self-Cultivation [New York: Peter Lang, 1993], pp. 12-13); and the preference for persuasion and transformative education over coercion as a means to achieve social and political order (see David L. Hall and Roger T. Ames, Thinking Through Confucius [Albany: State University of New York Press, 1987], pp. 169-170)—Confucianism did provide a philosophy that always (or nearly always) coexisted uneasily with the political status quo.

47 - See Huang Zongxi, Waiting for the Dawn: A Plan for the Prince, trans. Wm. Theodore de Bary (New York: Columbia University Press, 1993).

48 - See de Bary, "Introduction," in ibid., p. 7.

49 - See ibid., pp. xi-xii.

50 - See Nathan, Chinese Democracy, p. 68.

51 - This is de Bary's term in his "Introduction," in Waiting for the Dawn, p. 83.

52 - De Bary also makes this point in ibid., p. 55.

53 - The same criticism can be made of Sun Yat-sen's proposed constitution of five separate powers, which includes an independent branch responsible for setting civil service examinations. Under Sun's proposed scheme, all public officials, including those elected to the legislature, "must pass examinations before assuming office" (Selected Writings of Sun Yat-sen: Prescriptions for Saving China, ed. J. L. Lee, R. H. Myers, and D. G. Gillin [Stanford: Hoover Press, 1994], p. 49). Sun hoped to avoid "the corruption and laxity of American politics," where "those endowed with eloquence ingratiated themselves with the public and won elections, while those who had learning and ideals but lacked eloquence were ignored" (ibid.), but the effect would be to exclude from political power elected politicians who failed examinations. It is difficult to imagine that a government that completely excluded the "people's chosen leaders" could achieve much legitimacy in the "eyes of the people" (consider a situation where someone elected with 80 percent of the vote who fails examinations is replaced by a successful examination candidate who received only 20 percent of the vote).

54 - It is interesting to note, however, that it is not uncommon in "Confucian" countries such as Japan and Korea for defendants to be tried in court cases before judges in their twenties. In Korea, for example, judges need only to pass the bar exam and then go through a two-year program at the Legal Training Institute run by the Ministry of Justice, with the consequence that young persons in their twenties may preside as judges in Korea's courts. However, this may be the result of having adopted the "German-style" civil law tradition (as opposed to the "Confucian" emphasis on examinations as a means for selecting decision makers), and the Korean government is currently trying to mitigate 
some of the defects of this system by not allowing people to become judges until they serve some years as lawyers or prosecutors (I thank Hahm Chaibong for this information).

55 - Examinations for high-ranking members of the civil service in Hong Kong similarly test for the ability to "look at both sides" of controversial political issues.

56 - Winston Churchill's (apocryphal?) quip about democracy-that it's the worst possible political system, except for all the others-can also be used to defend the examination system as a procedure for identifying decision makers of talent and integrity.

57 - This point is well-articulated by Alan Blinder (see note 7 above), though he presents it as an argument for "the other side" (see "Is Government Too Political?" p. 126).

58 - According to Professor Onuma Yasuaki, however, Tokyo University is trying to improve the situation by placing more emphasis on creative answers to questions for the university entrance examinations.

59 - If the minimum age is moved too high, it can be argued that not many "senior citizens," particularly those successful at other careers, will be willing to sit through a rigorous examination process. One solution might be to let thirtyyear-olds write the exams and to seal the results for the next quarter century, at which point the results could be made public and successful candidates could assume their posts as deputies in the House of Scholars at the age of fifty-five (this system has another advantage: it would give a wide range of persons hope that they might be "successful" later on in life; this can keep them going through rough patches experienced between the ages of thirty and fifty-five). Of course, there will be a problem with selecting the first few batches of scholars if this system is put into place immediately.

60 - See Robert Dahl, Democracy and Its Critics (New Haven: Yale University Press, 1989), p. 64.

61 - I would like to thank Robert Dahl for this information (personal interview with the author).

62 - See Michael R. Dutton, Policing and Punishment in China (Cambridge: Cambridge University Press, 1992), chap. 4.

63 - See Perry Link, Evening Chats in Beijing (New York: Norton, 1992), pp. 106107.

64 - See, for example, "The Cuba Boomerang," New York Times editorial, 13 July 1996, p. 18. The New York Times is critical of this law, asking "How far, one wonders, does guilt by kinship extend?"

65 - Another option more respectful of the value of individual-based responsibility might be a law requiring that the state closely monitor the business dealings of 
the sons and daughters of public officials, but that the children only be punished in cases of actual misdeeds (I thank Joseph Chan for this point).

66 - See C. L. Chiou, Democratizing Oriental Despotism (New York: St. Martin's Press, 1995), p. 3.

67 - Kim Kwang-ok traces the value of respect for intellectuals in Korea back to its Confucian roots: "Since education is the most important mechanism by which people become proper human beings, jobs related to education, such as being a teacher or professor, are highly respected. The job of university professor is one of the most prestigious in Korea, as this represents the model of the noble man" (Kim, "The Reproduction of Confucian Culture in Contemporary Korea: An Anthropological Study," in Tu Wei-ming, Confucian Traditions in East Asian Modernity, p. 206).

68 - See Daniel Bell, "The Old War: After Ideology, Corruption," New Republic, 23 and 30 August 1993, pp. 20-21.

69 - See John Darnton, "Labor Peers into the Lords' Future," International Herald Tribune, 22 April 1996, pp. 1, 8.

70 - See Simon Macklin, "House of Lords to Oust Hereditary Peers," South China Morning Post, 11 June 1998, p. 14.

71 - The "cultural terrain" for a House of Scholars may be relatively favorable in France, given the social and political importance of French intellectuals. If the Fifth Republic experiences a serious political or constitutional crisis, perhaps a House of Scholars can be considered as a constitutional proposal for a "Sixth Republic."

72 - According to He Huai Hong, this perception was often grounded in fact; that is, civil service examinations did often serve as a vehicle for upward social mobility (and downward social mobility for established families that could not produce successful offspring). See his "Rujia de pingdeng guan jiqi zhiduhua" (Confucianism's equality and its institutionalization) (paper presented at a conference on "Confucianism and Human Rights," Beijing University, June 1998). It is also worth noting that standardized (blindly graded) testing has also been an instrument of upward mobility in France, the United Kingdom, and the United States (see Adrian Woodridge, "A True Test," New Republic, 15 June 1998, pp. 20-21).

73 - It may be worth noting that several persons (including myself) are currently involved in a project to draft a constitution for a Confucian democracy (meant to be particularly relevant for Korea), which may include this proposal for an upper House of Scholars. This effort is part of a multi-year series of workshops on Confucianism and democracy, organized by Professor Hahm Chaibong of Yonsei University in Seoul, Korea.

74 - Minority groups can also be guaranteed representation in the democratic lower 
house, as in Yan Jiaqi's proposal for a federal system in post-Communist China (see his article "China's National Minorities and Federalism," Dissent, Summer 1996). More generally, it is worth emphasizing that the House of Scholars proposal is fully compatible with federal constitutional mechanisms regulating the relationship between national and provincial institutions: in fact, those favoring more local autonomy may have an interest in supporting a proposal for a House of Scholars, because deputies in the House of Scholars bound by term limits may be more likely to ensure that decisions at the local level are not usurped by national political institutions (in contrast to relatively "powerhungry" bureaucrats with lifetime tenure and ambitious politicians concerned about the next election).

75 - See note 63 above.

76 - It is worth noting, however, that not every Chinese intellectual will readily admit the possibility that different persons can (justifiably) settle upon different interpretations of the common good. According to Thomas Metzger, many Chinese intellectuals, including self-described liberals, seem to believe that "specific normative problems can all be solved in an objective way based on "reason"; that the ultimate nature of all things ... can be known; and that all knowledge can be organized to form a single unified system of thought which an enlightened elite can then use to guide society" (Thomas Metzger, "On Chinese Tendencies Resisting Democratization" [paper included in folder distributed to participants of a workshop on "Confucianism and Democracy," June 1998, Jirae, Korea], p. 6). This outlook can pose a problem for a political institution that depends on the willingness of members to abide by the decisions of the majority in cases of conflict between competing interpretations of the common good.

77 - Perhaps Wang could have suggested the possibility of a referendum, to gauge "the people's" support for a House of Scholars with the power to override the decisions of a democratic lower house. But this may be asking Wang to take a needless risk, since it may be preferable to settle for a purely advisory House of Scholars that is not put to a referendum. And even if the majority votes for a powerful House of Scholars, the system may not be stable for the long term, as future (more educated?) generations may come to object to this political arrangement.

Another possibility would be to give majorities in the upper house the power to override majorities in the lower house, but then allowing a supermajority (say, two-thirds of the representatives) in the lower house to override majorities in the upper house. This way, the upper house could exercise more de facto power, but the "ultimate" power would still lie with the "people's" representatives in the lower house. It is unlikely, however, that democrats could accept a proposal that effectively disempowers the lower house to this extent.

78 - This leads to the question of whether representatives of the lower house should 
also be subject to term limits. If they are not, an upper house whose members are limited to seven or eight years may not be able to stand up to a lower house whose members are longtime insiders.

79 - If the House of Scholars plays a purely advisory role, perhaps it should deliberate about public policies and legal judgments. But if it plays a more active decision-making role, there is more reason to worry about the need to separate the powers of the House of Scholars and the judiciary.

80 - Other important "details" include the question of scale (perhaps the House of Scholars should be limited to two or three hundred seats, so as to allow for high-quality deliberations), the question of how to further insulate members of the House of Scholars from political pressure (perhaps they should be barred from joining political parties and be forced to disclose publicly memberships with interest groups, similar to the mechanisms that help to ensure the integrity of federal judges in the U.S.), and the question of who should determine the content of the exams used to select deputies for the House of Scholars (perhaps a committee from the lower house should have the final say on the matter, which may help to alleviate the concerns of democrats; I thank Mak Tsz Kwan, a student from the "Theories of Society" class, University of Hong Kong, Spring 1997, for this suggestion).

81 - One exception is Solzhenitsyn's 1991 pamphlet "How We Are to Rebuild Russia," which sought to rebuild Russian national pride by drawing on prerevolutionary models (he proposed to recreate the elected district councils of prerevolutionary times and the Duma, the first Russian Parliament in 1905, and to revive the Orthodox Church), but without some of the antidemocratic and colonialist elements of Russian nationalism. This proposal never did gain widespread support, however-perhaps because it was paired in people's minds with Solzhenitsyn's oft-displayed hostility to secular, "consumerist" modernity. 